\title{
Cell Cycle Inhibition without Disruption of Neurogenesis Is a Strategy for Treatment of Aberrant Cell Cycle Diseases: An Update
}

\author{
Da-Zhi Liu and Bradley P. Ander \\ Department of Neurology and the MIND Institute, University of California at Davis, Sacramento, CA 95817, USA \\ Correspondence should be addressed to Da-Zhi Liu, dzliu@ucdavis.edu
}

Received 13 October 2011; Accepted 17 November 2011

Academic Editors: F. Bareyre and B. K. Jin

Copyright (C) 2012 D.-Z. Liu and B. P. Ander. This is an open access article distributed under the Creative Commons Attribution License, which permits unrestricted use, distribution, and reproduction in any medium, provided the original work is properly cited.

Since publishing our earlier report describing a strategy for the treatment of central nervous system (CNS) diseases by inhibiting the cell cycle and without disrupting neurogenesis (Liu et al. 2010), we now update and extend this strategy to applications in the treatment of cancers as well. Here, we put forth the concept of "aberrant cell cycle diseases" to include both cancer and CNS diseases, the two unrelated disease types on the surface, by focusing on a common mechanism in each aberrant cell cycle reentry. In this paper, we also summarize the pharmacological approaches that interfere with classical cell cycle molecules and mitogenic pathways to block the cell cycle of tumor cells (in treatment of cancer) as well as to block the cell cycle of neurons (in treatment of CNS diseases). Since cell cycle inhibition can also block proliferation of neural progenitor cells (NPCs) and thus impair brain neurogenesis leading to cognitive deficits, we propose that future strategies aimed at cell cycle inhibition in treatment of aberrant cell cycle diseases (i.e., cancers or CNS diseases) should be designed with consideration of the important side effects on normal neurogenesis and cognition.

\section{Introduction}

The cell cycle is an irreversible, ordered set of events that normally leads to cellular division [1-5]. The release of cells from a quiescent state (G0) results in their entry into the first gap phase (G1), during which the cells prepare for DNA replication in the synthetic phase $(\mathrm{S})$. This is followed by the second gap phase (G2) and mitosis phase (M). After the cell has split into its two daughter cells, the new cells enter either G1 or G0. Tumors usually originate from adult tissues, in which the majority of cells are in the G0 quiescent phase [4]. Mature neurons normally maintain themselves in G0 resting phase. These facts suggest that the cells that go on to form tumors and mature neurons share a common G0 state of quiescence.

Since cell cycle is irreversible, this raises a possibility that irreversible cell cycle reentry mediates the irreversible neuronal death that mirrors the irreversible progression of some central nervous system (CNS) diseases, such as Alzheimer's disease $(A D)$. If this is true, it will partially explain why $A D$ is incurable once even early AD symptoms occur, for the early $\mathrm{AD}$ symptoms may indicate that the neurons have reentered the cell cycle that ends up leading to neuronal death and $\mathrm{AD}$ progression. Thus, the best strategy in treatment of CNS diseases is to prevent cell cycle re-entry at the early stage before neurons leave the G0 phase at all, since even the mere entrance into the initial cell cycle may lead to unavoidable neuronal death.

Since re-entry into the cell cycle by tumor cells or neurons has been associated with many tumor or CNS diseases and linked to uncontrolled cell proliferation (in cancer) or neuronal death (in CNS diseases), cell cycle inhibition strategies are of interest in the treatment of both tumor and CNS diseases. For instance, the cell cycle inhibitors, such as cyclin-dependent kinase (CDK) inhibitors, have been widely studied as cancer therapeutics. They have been used to inhibit growth of several types of tumor cells in numerous preclinical studies, both in vitro and in vivo [6-12]. Several 
cell cycle inhibitors have advanced to human clinical trials for evaluation as a treatment for a broad range of solid tumors and hematological malignancies such as chronic lymphocytic leukemia (CLL) [13-17]. Though no clinical trials of the cell cycle inhibitors are reported in the treatment of CNS diseases, preclinical experiments demonstrate that the cell cycle inhibitors improve behavioral outcomes and increase neuronal survival in a series of CNS disease models [1833].

Cell cycle inhibition kills tumor cells (in treatment of cancer) or protects mature neurons from death (in treatment of CNS diseases), whereas this can also block proliferation of neural progenitor cells (NPCs) and thus impair brain neurogenesis leading to cognitive deficits in the patients of cancer and CNS diseases [1]. Since the presence of cognitive deficits is a major factor markedly affecting quality of life of these patients, the cell cycle inhibition strategy in treatment of cancer and CNS diseases should consider the consequences on other cell types that can be affected, such as NPCs.

As a way to describe the two seemingly different disease types (i.e., cancer and CNS diseases) that share the common mechanism of cell cycle re-entry, we propose a broader term of "aberrant cell cycle diseases"-one which includes not only cancers but also CNS diseases. A detailed description of how the cell cycle re-entry, at least in part, underlies cancers and CNS diseases follows before we discuss the pharmacological approaches that have been examined in therapeutic treatment of the two disease types.

\section{Aberrant Cell Cycle Diseases: Cancers and CNS Diseases}

Cancers and CNS diseases are two major threats to human health. Epidemiological studies show that patients with CNS disease, such as Alzheimer's disease (AD), Parkinson's disease (PD), Huntington's disease (HD), and multiple sclerosis (MS), have a significantly lower risk of most cancers [3438]. The reverse correlations also hold true: cancer survivors have a significantly lower risk of developing some of these CNS diseases. However, there are exceptions: Parkinson's patients have an increased risk for melanoma [39-44], autism patients have an increased risk for breast cancer [45], and Fragile X Syndrome patients have increased risk for lip cancer [46]. No matter what associations underlie certain cancers and CNS diseases, these correlative studies have raised an interesting question: what associated processes or mechanisms do dying neurons and growing tumor cells have in common?

Aberrant cell cycle is the hallmark of many tumor cells in cancers [47-49] and is also observed in postmortem and/or animal studies of dying neurons in a series of CNS diseases, such as $\mathrm{AD}, \mathrm{PD}$, stroke, epilepsy, cerebral hypoxia-ischemia, amyotrophic lateral sclerosis (ALS), traumatic brain injury (TBI), among others [18-33, 50-64]. Although tumor cells undergo uncontrolled proliferation, many tumors originate from adult tissues in which the majority of cells are in the G0 quiescent phase [4]. Similarly, mature neurons stay in G0 quiescent phase in normal physiological conditions, but do reenter the cell cycle irregularly (and die) in certain pathological conditions.

Thus, the cells that go on to form tumors and healthy neurons share a common G0 state of quiescence. However, if tumor cells re-enter the cell cycle, they survive and often proliferate, whereas mature neurons will die. Therefore, cell cycle inhibition can be applied not only to kill tumor cells (in treatment of cancer), but also to protect neurons from death (in treatment of CNS diseases). This is strongly supported by the findings that mutation of PARK2, a tumor suppressor gene, results not only in neuronal death in Parkinson's disease, but also in tumor cell proliferation in glioblastoma and other human cancer [65]. Consistently, cell cycle inhibition mot only promotes the death of naive PC12 (pheochromocytoma) tumor cells, but also prevents the death of nerve growth factor- (NGF-) differentiated PC12 neuronal cells $[66,67]$.

\section{Cell Cycle and "Expanded Cell Cycle"}

Classically, the proteins and regulators of the cell cycle include CDKs, cyclins, CDK inhibitors, and CDK substrates. However, the cell cycle inhibition strategies that target on these molecules lack specificity for their target tumor cells or dying neurons and thus interfere the normal biological processes performed by other cell types, since the core cell-cycle-associated molecules are often highly conserved throughout eukaryotes, thus we proposed an "expanded cell cycle" to include not only the core cell cycle molecules mentioned above, but also the mitogenic molecules and the signaling pathways that interact with them. Under specific environmental and/or pathological conditions, such as exposure of tobacco smoke, benzene, ultraviolet B radiation, and/or enhancement of mitogenic molecules (i.e., thrombin, growth factors, amyloid beta, etc.), activation of specific pathways to mediate abnormal cell cycle re-entry may arise and thus trigger tumorigenesis of normal cells and/or death of neurons. It is always impossible to prove exactly what caused a cancer or CNS disease in any individual, because most of these diseases have multivariate causes. However, the various causes seem to result in a common outcome-cell cycle re-entry, mediated by several common mitogenic pathways. The main mitogenic pathways include (1) FAK/Src/Ras/Raf/MEK1, 2/ERK1, 2 $\rightarrow$ cell cycle re-entry [68-72]; (2) Ras/Rac1/MEK3, 6/P38 $\rightarrow$ cell cycle re-entry $[73,74]$; (3) $\mathrm{PLC} / \mathrm{IP} 3 / \mathrm{PKC} / \mathrm{JNK} \rightarrow$ cell cycle re-entry $[75,76]$; (4) PI3K/Akt/mTOR/Tau $\rightarrow$ cell cycle re-entry $[60,77,78]$; (5) JAK/STAT $\rightarrow$ cell cycle re-entry $[79,80]$. In addition, many molecules, including ROS, $\mathrm{PGE}_{2}$, $\mathrm{NO}$, and $\mathrm{Ca}^{2+}$, can directly or indirectly participate in the main mitogenic signaling pathways [8186]. The idea of an "expanded cell cycle" provides a wider view encompassing a broad range of molecules representing potential targets and thus approaches that can serve as treatments for cancer and CNS diseasesall sharing the common outcome of cell cycle inhibition. 
TABLE 1: Pharmacological approaches interfering with mitogenic molecules and signaling pathways of the "expanded cell cycle" in treatments of cancer and CNS diseases.

Treatments

\begin{tabular}{lcc} 
Targets & \multicolumn{2}{c}{ Cancers } \\
& Agents & Stages \\
\hline & Flavopiridol, & \\
& Indisulam, & \\
& AZD5438 & \\
& SNS-032 & \\
CDK & Bryostatin-1 & Clinical trials in a broad range of solid \\
inhibitors & Seliciclib & tumors and chronic lymphocytic leukemia \\
& PD 0332991 & (CLL) [13-16]. \\
& SCH 727965 & \\
& UCN-01, & \\
& Roscovitine, & \\
& AT7519
\end{tabular}

\begin{tabular}{|c|c|c|c|c|}
\hline Antioxidants & Isoliquiritigenin & Experimental trials in prostate cancer [124]. & $\begin{array}{c}\text { Edaravone } \\
\text { NXY-059 } \\
\text { Coenzyme } \\
\text { Q10 } \\
\text { Vitamin E } \\
\text { Melatonin } \\
\text { Trolox } \\
\text { SOD } \\
\text { NAC } \\
\text { PBN } \\
\end{array}$ & $\begin{array}{l}\text { Clinical use in stroke in Asia [125, 126], } \\
\text { Clinical trials in stroke [126], AD } \\
\text { [127-129], ALS [130-132]. } \\
\text { Experimental trials in ALS [133], PD [134], } \\
\text { SCI [135]. }\end{array}$ \\
\hline $\begin{array}{l}\text { i/eNOS } \\
\text { inhibitors }\end{array}$ & $\begin{array}{l}\text { L-NAME } \\
\text { AMT } \\
\text { NPA }\end{array}$ & Experimental trials in prostate cancer [136]. & $\begin{array}{l}\text { L-NAME } \\
\text { AMT } \\
\text { NPA }\end{array}$ & Experimental trials in ICH [137], SCI [135]. \\
\hline $\begin{array}{l}\text { Cox-2 } \\
\text { inhibitors }\end{array}$ & $\begin{array}{l}\text { Celecoxib } \\
\text { Rofecoxib } \\
\text { NS-398 }\end{array}$ & $\begin{array}{c}\text { Clinical trials in bladder cancer [138], lung } \\
\text { cancer [139, 140], head and neck cancer } \\
\text { [141], pancreatic cancer [142], prostate } \\
\text { cancer [143], breast cancer [144], colorectal } \\
\text { cancer [145]. } \\
\text { Experimental trials in pancreatic cancer } \\
\text { [146], prostate cancer [147], esophageal } \\
\text { cancer [148], colon cancer [149]. }\end{array}$ & $\begin{array}{l}\text { Celecoxib } \\
\text { Rofecoxib } \\
\text { NS-398 }\end{array}$ & $\begin{array}{l}\text { Clinical trials in AD [150, 151]. } \\
\text { Experimental trials in ICH [137]. }\end{array}$ \\
\hline $\begin{array}{l}\mathrm{Ca}^{2+} \text { channel } \\
\text { blockers }\end{array}$ & KYS05090 & Experimental trials in cancers [152]. & Flunarizine & Clinical trials in stroke [153]. \\
\hline $\begin{array}{l}\text { Glutamatergic } \\
\text { modulators }\end{array}$ & MK-801 & $\begin{array}{l}\text { Experimental trials in breast cancer [154], } \\
\text { brain tumors [155]. }\end{array}$ & $\begin{array}{c}\text { Riluzole } \\
\text { Ceftriaxone } \\
\text { Talampanel } \\
\text { MK-801 } \\
\text { NBQX }\end{array}$ & $\begin{array}{c}\text { Clinical trials in ALS }[156] \text {. } \\
\text { Experimental trials in TBI }[157,158], \text { SCI } \\
\text { [159], ICH }[160], \text { stroke }[161] .\end{array}$ \\
\hline $\begin{array}{l}\text { NMDA- } \\
\text { receptor } \\
\text { modulators }\end{array}$ & AP5 Memantine & $\begin{array}{l}\text { Experimental trials in breast cancer [154], } \\
\text { gastric cancer [162]. }\end{array}$ & Memantine & $\begin{array}{c}\text { Clinical use in AD [163-166]. } \\
\text { Clinical trials in ALS [156]. } \\
\text { Off-label use in psychiatric disorders [167]. } \\
\text { Experimental trials in TBI [168], ICH [169], } \\
\text { stroke [170], }\end{array}$ \\
\hline $\begin{array}{l}\text { Thrombin } \\
\text { inhibitors }\end{array}$ & Heparin & Experimental trials in lung cancer [171]. & $\begin{array}{l}\text { Heparin } \\
\text { Hirudin }\end{array}$ & $\begin{array}{l}\text { Experimental trials in ischemic stroke [172], } \\
\text { ICH }[118,173,174] .\end{array}$ \\
\hline $\begin{array}{l}\text { Thrombin } \\
\text { receptor-1 } \\
\text { antagonist } \\
\end{array}$ & $\begin{array}{l}\text { RWJ-58259 } \\
\text { SCH-79797 }\end{array}$ & Experimental trials in colon cancer [175]. & BMS-200261 & $\begin{array}{l}\text { Experimental trials in stroke [176]; PD } \\
\text { [177]. }\end{array}$ \\
\hline Ras inhibitors & $\begin{array}{l}\text { Lovastatin } \\
\text { FTS }\end{array}$ & $\begin{array}{l}\text { Clinical trials in neurofibroma [178], head } \\
\text { and neck cancer [179]. } \\
\text { Experimental trials in neurofibroma [180], } \\
\text { liver cancer [181], ovarian cancer [182], } \\
\text { breast cancer [183], prostate cancer [184], } \\
\text { lung cancer [185]. }\end{array}$ & $\begin{array}{l}\text { Lovastatin } \\
\text { Exoenzyme }\end{array}$ & $\begin{array}{l}\text { Clinical trials in acute ischemic stroke } \\
\qquad[186,187] \text {. } \\
\text { Experimental trials in motor neuron } \\
\text { disorders }[188,189] .\end{array}$ \\
\hline
\end{tabular}

Flavopiridol Experimental trials in $\mathrm{AD}$ [18-22], PD [21], Olomoucine stroke [23, 24], TBI [25, 26], SCI [27, 28], Roscovitine excitotoxic stress [29-32], optic nerve Quinazolines transaction [33].

\section{CNS diseases}

Agents

Stages 
TABle 1: Continued.

\begin{tabular}{|c|c|c|c|c|}
\hline \multirow{3}{*}{ Targets } & \multicolumn{4}{|c|}{ Treatments } \\
\hline & \multicolumn{2}{|r|}{ Cancers } & \multicolumn{2}{|r|}{ CNS diseases } \\
\hline & Agents & Stages & Agents & Stages \\
\hline Src Inhibitors & $\begin{array}{l}\text { KX-01 } \\
\text { Dasatinib } \\
\text { PP1 } \\
\text { PP2 } \\
\text { Saracatinib }\end{array}$ & $\begin{array}{c}\text { Clinical trials in breast cancer [190-192]. } \\
\text { Experimental trials in breast cancer [193], } \\
\text { lung cancer [194, 195], cervical cancer } \\
\text { [196], renal cancer [197], prostate cancer } \\
{[198] .}\end{array}$ & $\begin{array}{l}\text { PP1 } \\
\text { PP2 }\end{array}$ & $\begin{array}{l}\text { Experimental trials in ICH }[91,199], \mathrm{AD} \\
{[70] .}\end{array}$ \\
\hline $\begin{array}{l}\text { JAK/Stat } \\
\text { Inhibitors }\end{array}$ & $\begin{array}{c}\text { EGCG } \\
\text { WP-1034 }\end{array}$ & $\begin{array}{c}\text { Experimental trials in prostate cancer [200], } \\
\text { breast cancer [201], lung cancer [202], } \\
\text { pancreatic cancer [203], acute myeloid } \\
\text { leukemia [204]. }\end{array}$ & EGCG & $\begin{array}{l}\text { Experimental trials in AD, PD, HIV } \\
\text { associated Dementia, multiple sclerosis } \\
\text { (MS), ALS, or Pick's Disease [79]. }\end{array}$ \\
\hline $\begin{array}{l}\text { GSK-3 } \beta \\
\text { inhibitors }\end{array}$ & $\begin{array}{l}\text { Lithium } \\
\text { SB } 415286 \\
\text { SB } 216763 \\
\text { AR-A014418 }\end{array}$ & $\begin{array}{l}\text { Experimental trials in colon cancer [205], } \\
\text { neuroblastoma [206]. }\end{array}$ & $\begin{array}{l}\text { L803-mt } \\
\text { Lithium } \\
\text { Kenpaullone } \\
\text { Indirubin } \\
\text { SB } 216763 \\
\text { SB } 415286\end{array}$ & $\begin{array}{c}\text { Experimental trials in AD [207-212], PD } \\
{[213], \text { brain injury [214]. }} \\
\text { Clinical trials in ALS }[156,215] .\end{array}$ \\
\hline $\begin{array}{l}\text { PI3K } \\
\text { inhibitors }\end{array}$ & $\begin{array}{l}\text { NVP-BEZ235 } \\
\text { GSK2126458 }\end{array}$ & Experimental trials in breast cancer [216]. & LY 294002 & Experimental trials in AD [217], PD [218]. \\
\hline Akt Inhibitors & $\begin{array}{c}\text { Perifosine } \\
\text { MK-2206 } \\
\text { RX-0201 } \\
\text { PBI-05204 } \\
\text { GSK2141795 } \\
\end{array}$ & Clinical trials in advanced cancer $[219,220]$. & LY 294002 & Experimental trials in AD [217], PD [218]. \\
\hline m-TOR & $\begin{array}{l}\text { Everolimus } \\
\text { Temsirolimus }\end{array}$ & $\begin{array}{c}\text { Clinical use in pancreatic cancer [221], renal } \\
\text { cancer [221]. } \\
\text { Clinical trials in epithelial ovarian } \\
\text { cancer/primary peritoneal cancer [222], } \\
\text { Endometrial Cancer [223], glioblastoma } \\
\text { [224], breast cancer [225], neuroendocrine } \\
\text { tumours [226], lung cancer [227], bladder } \\
\text { cancer [228], renal cancer [229, 230]. }\end{array}$ & Rapamycin & $\begin{array}{l}\text { Experimental trials in AD [231], PD [232], } \\
\text { TBI }[233,234] \text {, SCI }[235,236] \text {, stroke [237]. }\end{array}$ \\
\hline Tau inhibitor & SG410 & Experimental trials in pancreas cancer [238]. & TRx-0014 & Clinical use in $\operatorname{AD}[239,240]$. \\
\hline $\begin{array}{l}\text { ERK1/2 kinase } \\
\text { pathway }\end{array}$ & PD98059 & $\begin{array}{l}\text { Experimental trials in prostate cancer [241], } \\
\text { lung cancer [242]. }\end{array}$ & PD98059 & Experimental trials in ICH $[72,92]$. \\
\hline $\begin{array}{l}\text { P38 kinase } \\
\text { pathway }\end{array}$ & SB203580 & Experimental trials in colon cancer [243]. & $\begin{array}{l}\text { SB203580 } \\
\text { SB239063 }\end{array}$ & $\begin{array}{l}\text { Experimental trials in ICH [92], PD [244], } \\
\text { stroke [245]. }\end{array}$ \\
\hline $\begin{array}{l}\text { JNK kinase } \\
\text { pathway }\end{array}$ & SP600125 & $\begin{array}{l}\text { Experimental trials in cancer cells } \\
\qquad[246,247] .\end{array}$ & $\begin{array}{l}\text { CEP-1347 } \\
\text { Colostrinin } \\
\text { SP600125 }\end{array}$ & $\begin{array}{l}\text { Experimental trials in ICH }[72,92], \mathrm{AD} \\
{[248,249], \text { stroke }[250], \mathrm{PD}[248,250] .}\end{array}$ \\
\hline $\begin{array}{l}\text { Amino-5-(4-n } \\
\text { mino-5,6-dihy } \\
\text {-amino-5-phos } \\
\text { Methyl-10,11- } \\
\text { (omega)-prop }\end{array}$ & $\begin{array}{l}\text { lphenyl)-7-(t } \\
\text { 6-methyl- } 4 \mathrm{H} \text { - } \\
\text { novaleric acic } \\
\text { dro-5H-diber } \\
\text { arginine (NPA }\end{array}$ & $\begin{array}{l}\text { utyl)pyrazolo(3,4-d)pyrimidine (PP1), 4-Amino } \\
\text { 3-thiazine hydrochloride (AMT), 2,3-Dihydroxy- } \\
\text { (AP5), Epigallocatechin-3-gallate (EGCG), Farnesy } \\
\text { [a,d]cyclohepten-5,10-imine (MK 801), N-acytyl- } \\
\text { Phenyl-N-tert-butylnitrone (PBN), Superoxide disn }\end{array}$ & $\begin{array}{l}\text {-5-(4-chlorophen } \\
\text { 6-nitro-7-sulfame } \\
\text { lthiosalicylic acic } \\
\text {-L-cysteine (NAC }\end{array}$ & $\begin{array}{l}\text { nyl)-7(t-butyl)pyrazol(3,4-d)pyramide (PP2), } \\
\text { oyl-benzo [f] quinoxaline-2,3-dione (NBQX), Dl- } \\
\text { d (FTS), Methylthioinnium chloride (TRx-0014) } \\
\text { C), N(G)-nitro-l-arginine methyl ester (l-NAME) }\end{array}$ \\
\hline
\end{tabular}

\section{Pharmacological Approaches Interfering with the "Expanded Cell Cycle" in Treatment of Aberrant Cell Cycle Diseases}

In theory any part of the "expanded cell cycle" could act as a potential target for drug discovery. For example, thrombin activation is substantially increased in cancers [8789] and CNS diseases (i.e., AD, stroke). Thrombin may then go on to activate Src kinases $[90,91]$. Src kinases will activate MAPK which will activate CDK4/cyclinD complexes and promote cell cycle re-entry [71, 91, 92]. Thus, these molecules (thrombin, Src kinases, and MAPK), while not considered traditional components of the cell cycle, would all be considered part of the "expanded cell cycle." Similarly, other protein kinases (including JAK, Akt, PKC, JNK, ERK, GSK-3 $\beta$.) are also important molecules in the mitogenic pathways leading to neuronal cell cycle re-entry. Most targets mentioned above have been examined in cancer therapies 
as well as in CNS diseases. Pharmacological approaches based on those targets include traditional cell cycle inhibitors (CDK inhibitors), antioxidants, NMDA-receptor modulators, i/eNOS inhibitors, COX-2 inhibitors, protein kinase inhibitors, and others (Table 1).

\section{Cognitive Side Effects of Clinic Therapies for Aberrant Cell Cycle Diseases}

In treatment of peripheral or brain cancers, surgical removal of the tumor is recommended whenever possible. Anticancer medications (chemotherapy, CT) may be prescribed, as well as radiation therapy (RT). CT- or RT is cytotoxic, not only slowing down or killing rapidly dividing cells and producing many different types of DNA damage [93], but detrimentally leading to damage of normal tissue, especially of fast-growing healthy cells, including neural progenitor cells (NPCs), and also red and white blood cells [94, 95]. Recent reports show that CT results in cognitive side effects in extracranial cancer (i.e., breast cancer, prostate, etc.) patients [96-98], and CT or RT has also been associated with neurogenesis impairment and long-term cognitive deficits in brain cancer patients [99-105]. The main idea that is thought to contribute to the CT or RT-induced cognitive decline is that these treatments block proliferation of NPCs in the hippocampal and periventricular zones, which cannot be repopulated as healthy cells die. This leads to cognitive decline, since the NPCs help maintain neurogenesis [106109], repair damage from brain injury [105, 109-118], and are important in cognition [119-121].

Besides the CT and RT mentioned above in treatment of cancers, some pharmacological approaches that interfere with classical cell cycle molecules or mitogenic pathways have been examined in cancer and CNS disease therapies (Table 1). Therapies directed at any component inhibiting the cell cycle must be as specific as possible considering cell cycle re-entry contributes to the proliferation of tumor cells, the death of mature neurons, and the genesis of NPCs in adult brain. Therefore, any therapeutics that prevent tumor growth and/or neuronal death by blocking cell cycle reentry may have limited benefit because they may impair neurogenesis and thus lead to cognitive side effects. This may provide at least a partial explanation for the questionable efficacy of some currently approved drugs, such as the NMDA receptor modulator Memantine, in the clinical treatment of $\mathrm{AD}$ [122], since NMDA receptor inhibition has been shown to block progenitor cell proliferation and lead to impaired neurogenesis [123].

The cognitive side effects may be explained by the fact that current cell cycle inhibition strategies are not cell specific and also block the proliferation of important brain progenitor cells, thus impairing adult brain neurogenesis. If drugs that block the cell cycle are used to kill tumor cells (in treatment of cancer) and/or help protect neurons (in treatment of CNS diseases), it is likely that compounds would need to directly (or indirectly) block tumor and neuronal cell cycle re-entry and yet not affect the ongoing process of neurogenesis. This will only be possible if the signaling mechanisms are different in NPCs that divide in the adult brain, versus tumor cells and neurons that re-enter the cell cycle irregularly.

\section{Conclusions}

Cancer and CNS diseases, two seemingly different disease types, at least in part share the common molecular pathology of cell cycle re-entry. With this knowledge in mind, novel insights into cell cycle inhibition strategies to be used in treatment of the "aberrant cell cycle diseases" may be made. Future studies aimed at better understanding the respective cell cycle pathways of tumor cells, neurons, and NPCs are probably necessary before choosing the best drug targets for treating certain "aberrant cell cycle diseases" so as to consider the most effective benefits to the patient without causing indirect harm in related, but different systems.

\section{Acknowledgment}

The authors acknowledge the support of the University of California Innovative Development Award (D. Z. Liu).

\section{References}

[1] D. Z. Liu, B. P. Ander, and F. R. Sharp, "Cell cycle inhibition without disruption of neurogenesis is a strategy for treatment of central nervous system diseases," Neurobiology of Disease, vol. 37, no. 3, pp. 549-557, 2010.

[2] B. Novak, J. J. Tyson, B. Gyorffy, and A. Csikasz-Nagy, "Irreversible cell-cycle transitions are due to systems-level feedback," Nature Cell Biology, vol. 9, no. 7, pp. 724-728, 2007.

[3] C. Norbury and P. Nurse, "Animal cell cycles and their control," Annual Review of Biochemistry, vol. 61, pp. 441-470, 1992.

[4] M. Malumbres and M. Barbacid, "To cycle or not to cycle: a critical decision in cancer," Nature Reviews Cancer, vol. 1, no. 3, pp. 222-231, 2001.

[5] G. K. Schwartz and M. A. Shah, "Targeting the cell cycle: a new approach to cancer therapy," Journal of Clinical Oncology, vol. 23, no. 36, pp. 9408-9421, 2005.

[6] S. Erickson, O. Sangfelt, M. Heyman, J. Castro, S. Einhorn, and D. Grandér, "Involvement of the Ink4 proteins p16 and p15 in T-lymphocyte senescence," Oncogene, vol. 17, no. 5, pp. 595-602, 1998.

[7] G. I. Shapiro, D. A. Koestner, C. B. Matranga, and B. J. Rollins, "Flavopiridol induces cell cycle arrest and p53independent apoptosis in non-small cell lung cancer cell lines," Clinical Cancer Research, vol. 5, no. 10, pp. 2925-2938, 1999.

[8] M. Chien, M. Astumian, D. Liebowitz, C. Rinker-Schaeffer, and W. M. Stadler, "In vitro evaluation of flavopiridol, a novel cell cycle inhibitor, in bladder cancer," Cancer Chemotherapy and Pharmacology, vol. 44, no. 1, pp. 81-87, 1999.

[9] G. K. Schwartz, K. Farsi, P. Maslak, D. P. Kelsen, and D. Spriggs, "Potentiation of apoptosis by flavopiridol in mitomycin-C-treated gastric and breast cancer cells," Clinical Cancer Research, vol. 3, no. 9, pp. 1467-1472, 1997.

[10] F. Arguello, M. Alexander, J. A. Sterry et al., "Flavopiridol induces apoptosis of normal lymphoid cells, causes 
immunosuppression, and has potent antitumor activity in vivo against human leukemia and lymphoma xenografts," Blood, vol. 91, no. 7, pp. 2482-2490, 1998.

[11] M. Drees, W. A. Dengler, T. Roth et al., "Flavopiridol (L868275): selective antitumor activity in vitro and activity in vivo for prostate carcinoma cells," Clinical Cancer Research, vol. 3, no. 2, pp. 273-279, 1997.

[12] O. M. Tirado, S. Mateo-Lozano, and V. Notario, "Roscovitine is an effective inducer of apoptosis of Ewing's sarcoma family tumor cells in vitro and in vivo," Cancer Research, vol. 65, no. 20, pp. 9320-9327, 2005.

[13] P. G. Wyatt, A. J. Woodhead, V. Berdini et al., "Identification of N-(4-piperidinyl)-4-(2,6-dichlorobenzoylamino)-1Hpyrazole-3-carboxamide (AT7519), a novel cyclin dependent kinase inhibitor using fragment-based X-ray crystallography and structure based drug design," Journal of Medicinal Chemistry, vol. 51, no. 16, pp. 4986-4999, 2008.

[14] A. M. Senderowicz, "Flavopiridol: the first cyclin-dependent kinase inhibitor in human clinical trials," Investigational New Drugs, vol. 17, no. 3, pp. 313-320, 1999.

[15] S. R. Whittaker, R. H. Te Poele, F. Chan et al., "The cyclin-dependent kinase inhibitor seliciclib (R-roscovitine; CYC202) decreases the expression of mitotic control genes and prevents entry into mitosis," Cell Cycle, vol. 6, no. 24, pp. 3114-3131, 2007.

[16] A. M. Senderowicz and E. A. Sausville, "Preclinical and clinical development of cyclin-dependent kinase modulators," Journal of the National Cancer Institute, vol. 92, no. 5, pp. 376-387, 2000.

[17] M. A. Dickson and G. K. Schwartz, "Development of cellcycle inhibitors for cancer therapy," Current Oncology, vol. 16, no. 2, pp. 36-43, 2009.

[18] A. Copani, D. Ubertia, M. A. Sortino, V. Bruno, F. Nicoletti, and M. Memo, "Activation of cell-cycle-associated proteins in neuronal death: a mandatory or dispensable path?" Trends in Neurosciences, vol. 24, no. 1, pp. 25-31, 2001.

[19] E. Verdaguer, E. G. Jordá, A. M. Canudas et al., "Antiapoptotic effects of roscovitine in cerebellar granule cells deprived of serum and potassium: a cell cycle-related mechanism," Neurochemistry International, vol. 44, no. 4, pp. 251-261, 2004.

[20] E. G. Jorda, E. Verdaguer, A. M. Canudas et al., "Neuroprotective action of flavopiridol, a cyclin-dependent kinase inhibitor, in colchicine-induced apoptosis," Neuropharmacology, vol. 45, no. 5, pp. 672-683, 2003.

[21] I. Kruman and E. Schwartz, "Methods of neuroprotection by cyclin-dependent kinase inhibition," US 20080182853, 2006.

[22] M. R. Barvian, E. M. Dobrusin, J. S. Kaltenbronn et al., "Quinazolines and their use for inhibiting cyclin-dependent kinase enzymes," US 6982260, 2006.

[23] H. Osuga, S. Osuga, F. Wang et al., "Cyclin-dependent kinases as a therapeutic target for stroke," Proceedings of the National Academy of Sciences of the United States of America, vol. 97, no. 18, pp. 10254-10259, 2000.

[24] F. Wang, D. Corbett, H. Osuga et al., "Inhibition of cyclindependent kinases improves CA1 neuronal survival and behavioral performance after global ischemia in the rat," Journal of Cerebral Blood Flow and Metabolism, vol. 22, no. 2, pp. 171-182, 2002.

[25] S. Di Giovanni, V. Movsesyan, F. Ahmed et al., "Cell cycle inhibition provides neuroprotection and reduces glial proliferation and scar formation after traumatic brain injury,"
Proceedings of the National Academy of Sciences of the United States of America, vol. 102, no. 23, pp. 8333-8338, 2005.

[26] G. D. Hilton, B. A. Stoica, K. R. Byrnes, and A. I. Faden, "Roscovitine reduces neuronal loss, glial activation, and neurologic deficits after brain trauma," Journal of Cerebral Blood Flow and Metabolism, vol. 28, no. 11, pp. 1845-1859, 2008.

[27] S. Di Giovanni, S. M. Knoblach, C. Brandoli, S. A. Aden, E. P. Hoffman, and A. I. Faden, "Gene profiling in spinal cord injury shows role of cell cycle neuronal death," Annals of Neurology, vol. 53, no. 4, pp. 454-468, 2003.

[28] D. S. Tian, Z. Y. Yu, M. J. Xie, B. T. Bu, O. W. Witte, and W. Wang, "Suppression of astroglial scar formation and enhanced axonal regeneration associated with functional recovery in a spinal cord injury rat model by the cell cycle inhibitor olomoucine," Journal of Neuroscience Research, vol. 84, no. 5, pp. 1053-1063, 2006.

[29] D. S. Park, A. Obeidat, A. Giovanni, and L. A. Greene, "Cell cycle regulators in neuronal death evoked by excitotoxic stress: implications for neurodegeneration and its treatment," Neurobiology of Aging, vol. 21, no. 6, pp. 771-781, 2000.

[30] E. Verdaguer, A. Jiménez, A. M. Canudas et al., "Inhibition of cell cycle pathway by flavopiridol promotes survival of cerebellar granule cells after an excitotoxic treatment," Journal of Pharmacology and Experimental Therapeutics, vol. 308, no. 2, pp. 609-616, 2004.

[31] E. Verdaguer, E. G. Jordà, A. M. Canudas et al., "3-Amino thioacridone, a selective cyclin-dependent kinase 4 inhibitor, attenuates kainic acid-induced apoptosis in neurons," Neuroscience, vol. 120, no. 3, pp. 599-603, 2003.

[32] E. Verdaguer, E. G. Jordà, A. Stranges et al., "Inhibition of CDKs: a strategy for preventing kainic acid-induced apoptosis in neurons," Annals of the New York Academy of Sciences, vol. 1010, pp. 671-674, 2003.

[33] K. Lefèvre, P. G. H. Clarke, E. E. Danthe, and V. Castagné, "Involvement of cyclin-dependent kinases in axotomyinduced retinal ganglion cell death," Journal of Comparative Neurology, vol. 447, no. 1, pp. 72-81, 2002.

[34] C. M. Roe, M. I. Behrens, C. Xiong, J. P. Miller, and J. C. Morris, "Alzheimer disease and cancer," Neurology, vol. 64, no. 5, pp. 895-898, 2005.

[35] D. A. Bennett, "Is there a link between cancer and Alzheimer disease?” Neurology, vol. 75, no. 13, pp. 1216-1217, 2010.

[36] C. Becker, G. P. Brobert, S. Johansson, S. S. Jick, and C. R. Meier, "Cancer risk in association with Parkinson disease: a population-based study," Parkinsonism and Related Disorders, vol. 16, no. 3, pp. 186-190, 2010.

[37] S. A. Sørensen, K. Fenger, and J. H. Olsen, "Significantly lower incidence of cancer among patients with Huntington disease: an apoptotic effect of an expanded polyglutamine tract?" Cancer, vol. 86, no. 7, pp. 1342-1346, 1999.

[38] S. Hofer, M. Linnebank, and M. Weller, "Cancer risk among patients with multiple sclerosis and their parents," Neurology, vol. 74, no. 7, pp. 614-615, 2010.

[39] C. M. Clements, R. S. McNally, B. J. Conti, T. W. Mak, and J. P. Y. Ting, "DJ-1, a cancer- and Parkinson's diseaseassociated protein, stabilizes the antioxidant transcriptional master regulator Nrf2," Proceedings of the National Academy of Sciences of the United States of America, vol. 103, no. 41, pp. 15091-15096, 2006.

[40] R. Zanetti, S. Rosso, and D. I. Loria, "Parkinson's disease and cancer," Cancer Epidemiology Biomarkers and Prevention, vol. 16, no. 6, p. 1081, 2007. 
[41] A. Bajaj, J. A. Driver, and E. S. Schernhammer, "Parkinson's disease and cancer risk: a systematic review and meta-analysis," Cancer Causes and Control, vol. 21, no. 5, pp. 697-707, 2010.

[42] J. J. Ferreira, D. Neutel, T. Mestre et al., "Skin cancer and Parkinson's disease," Movement Disorders, vol. 25, no. 2, pp. 139-148, 2010.

[43] K. Garber, "Parkinson's disease and cancer: the unexplored connection," Journal of the National Cancer Institute, vol. 102, no. 6, pp. 371-374, 2010.

[44] H. Ren, K. Fu, C. Mu, B. Li, D. Wang, and G. Wang, "DJ-1, a cancer and Parkinson's disease associated protein, regulates autophagy through JNK pathway in cancer cells," Cancer Letters, vol. 297, no. 1, pp. 101-108, 2010.

[45] B. Crespi, "Autism and cancer risk," Autism Research, vol. 4, pp. 302-310, 2011.

[46] R. Sund, E. Pukkala, and K. Patja, "Cancer incidence among persons with fragile X syndrome in Finland: a populationbased study," Journal of Intellectual Disability Research, vol. 53, no. 1, pp. 85-90, 2009.

[47] J. Bartkova, M. Zemanova, and J. Bartek, "Expression of CDK7/CAK in normal and tumour cells of diverse histogenesis, cell-cycle position and differentiation," International Journal of Cancer, vol. 66, no. 6, pp. 732-737, 1996.

[48] M. Ishikaw, Y. Ogihara, and M. Miura, "Visualization of radiation-induced cell cycle-associated events in tumor cells expressing the fusion protein of Azami Green and the destruction box of human Geminin," Biochemical and Biophysical Research Communications, vol. 389, no. 3, pp. 426430, 2009.

[49] P. J. Smith, N. Marquez, M. Wiltshire et al., "Mitotic bypass via an occult cell cycle phase following DNA topoisomerase II inhibition in p53 functional human tumor cells," Cell Cycle, vol. 6, no. 16, pp. 2071-2081, 2007.

[50] Z. Nagy, M. M. Esiri, A. M. Cato, and A. D. Smith, "Cell cycle markers in the hippocampus in Alzheimer's disease," Acta Neuropathologica, vol. 94, no. 1, pp. 6-15, 1997.

[51] A. McShea, P. L. R. Harris, K. R. Webster, A. F. Wahl, and M. A. Smith, "Abnormal expression of the cell cycle regulators P16 and CDK4 in Alzheimer's disease," American Journal of Pathology, vol. 150, no. 6, pp. 1933-1939, 1997.

[52] J. Busser, D. S. Geldmacher, and K. Herrup, "Ectopic cell cycle proteins predict the sites of neuronal cell death in Alzheimer's disease brain," Journal of Neuroscience, vol. 18, no. 8, pp. 2801-2807, 1998.

[53] Y. Yang, D. S. Geldmacher, and K. Herrup, "DNA replication precedes neuronal cell death in Alzheimer's disease," Journal of Neuroscience, vol. 21, no. 8, pp. 2661-2668, 2001.

[54] Y. Yang, E. J. Mufson, and K. Herrup, "Neuronal cell death is preceded by cell cycle events at all stages of Alzheimer's disease," Journal of Neuroscience, vol. 23, no. 7, pp. 25572563, 2003.

[55] K. L. Jordan-Sciutto, R. Dorsey, E. M. Chalovich, R. R. Hammond, and C. L. Achim, "Expression patterns of retinoblastoma protein in Parkinson disease," Journal of Neuropathology and Experimental Neurology, vol. 62, no. 1, pp. 68-74, 2003.

[56] Z. Nagy and M. M. Esiri, "Neuronal cyclin expression in the hippocampus in temporal lobe epilepsy," Experimental Neurology, vol. 150, no. 2, pp. 240-247, 1998.

[57] S. Ranganathan and R. Bowser, "Alterations in G1 to S phase cell-cycle regulators during amyotrophic lateral sclerosis,"
American Journal of Pathology, vol. 162, no. 3, pp. 823-835, 2003.

[58] K. Herrup, R. Neve, S. L. Ackerman, and A. Copani, "Divide and die: cell cycle events as triggers of nerve cell death," Journal of Neuroscience, vol. 24, no. 42, pp. 9232-9239, 2004.

[59] Y. Yang, N. H. Varvel, B. T. Lamb, and K. Herrup, "Ectopic cell cycle events link human Alzheimer's disease and amyloid precursor protein transgenic mouse models," Journal of Neuroscience, vol. 26, no. 3, pp. 775-784, 2006.

[60] V. Khurana, Y. Lu, M. L. Steinhilb, S. Oldham, J. M. Shulman, and M. B. Feany, "TOR-mediated cell-cycle activation causes neurodegeneration in a Drosophila tauopathy model," Current Biology, vol. 16, no. 3, pp. 230-241, 2006.

[61] M. D. Nguyen, M. Boudreau, J. Kriz, S. Couillard-Després, D. R. Kaplan, and J. P. Julien, "Cell cycle regulators in the neuronal death pathway of amyotrophic lateral sclerosis caused by mutant superoxide dismutase 1," Journal of Neuroscience, vol. 23, no. 6, pp. 2131-2140, 2003.

[62] H. Imai, J. Harland, J. McCulloch, D. I. Graham, S. M. Brown, and I. M. Macrae, "Specific expression of the cell cycle regulation proteins, GADD34 and PCNA, in the peri-infarct zone after focal cerebral ischaemia in the rat," European Journal of Neuroscience, vol. 15, no. 12, pp. 1929-1936, 2002.

[63] M. O'Hare, F. Wang, and D. S. Park, "Cyclin-dependent kinases as potential targets to improve stroke outcome," Pharmacology and Therapeutics, vol. 93, no. 2-3, pp. 135-143, 2002.

[64] C. Y. Kuan, A. J. Schloemer, A. Lu et al., "Hypoxia-ischemia induces DNA synthesis without cell proliferation in dying neurons in adult rodent brain," Journal of Neuroscience, vol. 24, no. 47, pp. 10763-10772, 2004.

[65] S. Veeriah, B. S. Taylor, S. Meng et al., "Somatic mutations of the Parkinson's disease-associated gene PARK2 in glioblastoma and other human malignancies," Nature Genetics, vol. 42, no. 1, pp. 77-82, 2010.

[66] D. S. Park, S. E. Farinell, and L. A. Greene, "Inhibitors of cyclin-dependent kinases promote survival of post-mitotic neuronally differentiated PC12 cells and sympathetic neurons," Journal of Biological Chemistry, vol. 271, no. 14, pp. 8161-8169, 1996.

[67] D. S. Park, E. J. Morris, L. A. Greene, and H. M. Geller, "G1/S cell cycle blockers and inhibitors of cyclin-dependent kinases suppress camptothecin-induced neuronal apoptosis," Journal of Neuroscience, vol. 17, no. 4, pp. 1256-1270, 1997.

[68] A. Copani, F. Condorelli, A. Caruso et al., "Mitotic signaling by $\beta$-amyloid causes neuronal death," FASEB Journal, vol. 13, pp. 2225-2234, 1999.

[69] N. H. Varvel, K. Bhaskar, A. R. Patil, S. W. Pimplikar, K. Herrup, and B. T. Lamb, "A $\beta$ oligomers induce neuronal cell cycle events in Alzheimer's disease," Journal of Neuroscience, vol. 28, no. 43, pp. 10786-10793, 2008.

[70] R. Williamson, T. Scales, B. R. Clark et al., "Rapid tyrosine phosphorylation of neuronal proteins including tau and focal adhesion kinase in response to amyloid- $\beta$ peptide exposure: involvement of Src family protein kinases," Journal of Neuroscience, vol. 22, no. 1, pp. 10-20, 2002.

[71] H. Wang and G. Reiser, "Thrombin signaling in the brain: the role of protease-activated receptors," Biological Chemistry, vol. 384, no. 2, pp. 193-202, 2003.

[72] M. Ohnishi, H. Katsuki, S. Fujimoto, M. Takagi, T. Kume, and A. Akaike, "Involvement of thrombin and mitogen-activated protein kinase pathways in hemorrhagic brain injury," Experimental Neurology, vol. 206, no. 1, pp. 43-52, 2007. 
[73] J. Guan, Y. Luo, and B. M. Denker, "Purkinje cell protein2 (Pcp2) stimulates differentiation in PC12 cells by $\mathrm{G} \beta \gamma$ mediated activation of Ras and p38 MAPK," Biochemical Journal, vol. 392, no. 2, pp. 389-397, 2005.

[74] J. Segarra, L. Balenci, T. Drenth, F. Maina, and F. Lamballe, "Combined signaling through ERK, PI3K/AKT, and $\mathrm{RAC} 1 / \mathrm{p} 38$ is required for Met-triggered cortical neuron migration," Journal of Biological Chemistry, vol. 281, no. 8, pp. 4771-4778, 2006.

[75] P. Lopez-Bergami and Z. Ronai, "Requirements for PKCaugmented JNK activation by MKK4/7," International Journal of Biochemistry and Cell Biology, vol. 40, no. 5, pp. 10551064, 2008.

[76] Y. Dwivedi and G. N. Pandey, "Effects of treatment with haloperidol, chlorpromazine, and clozapine on protein kinase C (PKC) and phosphoinositide-specific phospholipase C (PI-PLC) activity and on mRNA and protein expression of PKC and PLC isozymes in rat brain," Journal of Pharmacology and Experimental Therapeutics, vol. 291, no. 2, pp. 688-704, 1999.

[77] X. Zhu, C. A. Rottkamp, H. Boux, A. Takeda, G. Perry, and M. A. Smith, "Activation of p38 kinase links tau phosphorylation, oxidative stress, and cell cycle-related events in Alzheimer disease," Journal of Neuropathology and Experimental Neurology, vol. 59, no. 10, pp. 880-888, 2000.

[78] B. Xing, T. Xin, R. L. Hunter, and G. Bing, "Pioglitazone inhibition of lipopolysaccharide-induced nitric oxide synthase is associated with altered activity of p38 MAP kinase and PI3K/ Akt," Journal of Neuroinflammation, vol. 5, article 4, 2008.

[79] J. Tan et al., "Neurodegenerative disease treatment using jAK/STAT inhibition,” PCT/US2008/055646, 2008.

[80] R. J. Goody, J. D. Beckham, K. Rubtsova, and K. L. Tyler, "JAK-STAT signaling pathways are activated in the brain following reovirus infection," Journal of NeuroVirology, vol. 13, no. 4, pp. 373-383, 2007.

[81] N. Li, C. Wang, Y. Wu, X. Liu, and X. Cao, "Ca2+/calmodulin-dependent protein kinase II promotes cell cycle progression by directly activating MEK1 and subsequently modulating p27 phosphorylation," Journal of Biological Chemistry, vol. 284, no. 5, pp. 3021-3027, 2009.

[82] L. M. Mao, Q. S. Tang, and J. Q. Wang, "Regulation of extracellular signal-regulated kinase phosphorylation in cultured rat striatal neurons," Brain Research Bulletin, vol. 78, no. 6, pp. 328-334, 2009.

[83] S. De Bernardo, S. Canals, M. J. Casarejos, R. M. Solano, J. Menendez, and M. A. Mena, "Role of extracellular signalregulated protein kinase in neuronal cell death induced by glutathione depletion in neuron/glia mesencephalic cultures," Journal of Neurochemistry, vol. 91, no. 3, pp. 667-682, 2004.

[84] A. Copani and F. Nicoletti, Cell-Cycle Mechanisms and Neuronal Cell Death, Kluwer Academic Publishers/Plenum, New York, NY, USA, 2005.

[85] J. Y. Qian, A. Leung, P. Harding, and M. C. LaPointe, "PGE2 stimulates human brain natriuretic peptide expression via EP4 and p42/44 MAPK," American Journal of Physiology, vol. 290, no. 5, pp. H1740-H1746, 2006.

[86] B. L. Fiebich, S. Schleicher, O. Spleiss, M. Czygan, and M. Hüll, "Mechanisms of prostaglandin E2-induced interleukin6 release in astrocytes: possible involvement of EP4-like receptors, p38 mitogen-activated protein kinase and protein kinase C," Journal of Neurochemistry, vol. 79, no. 5, pp. 950958, 2001.
[87] D. Darmoul, V. Gratio, H. Devaud, T. Lehy, and M. Laburthe, "Aberrant expression and activation of the thrombin receptor protease-activated receptor-1 induces cell proliferation and motility in human colon cancer cells," American Journal of Pathology, vol. 162, no. 5, pp. 1503-1513, 2003.

[88] L. Traby, A. Kaider, R. Schmid et al., "The effects of lowmolecular-weight heparin at two different dosages on thrombin generation in cancer patients: a randomised controlled trial," Thrombosis and Haemostasis, vol. 104, no. 1, pp. 9299, 2010.

[89] K. M. Snyder and C. M. Kessler, "The pivotal role of thrombin in cancer biology and tumorigenesis," Seminars in Thrombosis and Hemostasis, vol. 34, no. 8, pp. 734-741, 2008.

[90] H. Wang and G. Reiser, "The role of the Ca2+-sensitive tyrosine kinase Pyk2 and Src in thrombin signalling in rat astrocytes," Journal of Neurochemistry, vol. 84, no. 6, pp. 1349-1357, 2003.

[91] D. Z. Liu, X. Y. Cheng, B. P. Ander et al., "Src kinase inhibition decreases thrombin-induced injury and cell cycle re-entry in striatal neurons," Neurobiology of Disease, vol. 30, no. 2, pp. 201-211, 2008.

[92] S. Fujimoto, H. Katsuki, M. Ohnishi, M. Takagi, T. Kume, and A. Akaike, "Thrombin induces striatal neurotoxicity depending on mitogen-activated protein kinase pathways in vivo," Neuroscience, vol. 144, no. 2, pp. 694-701, 2007.

[93] G. Driessens, L. Harsan, P. Browaeys, X. Giannakopoulos, T. Velu, and C. Bruyns, "Assessment of in vivo chemotherapyinduced DNa damage in a p53-mutated rat tumor by micronuclei assay," Annals of the New York Academy of Sciences, vol. 1010, pp. 775-779, 2003.

[94] G. Van Kaick and S. Delorme, "Therapy-induced effects in normal tissue," Radiologe, vol. 48, no. 9, pp. 871-880, 2008.

[95] K. Lucas, M. J. Gula, and J. Blatt, "Relapse in acute lymphoblastic leukemia as a function of white blood cell and absolute neutrophil counts during maintenance chemotherapy," Pediatric Hematology and Oncology, vol. 9, no. 2, pp. 91-97, 1992.

[96] J. S. Wefel, A. K. Saleeba, A. U. Buzdar, and C. A. Meyers, "Acute and late onset cognitive dysfunction associated with chemotherapy in women with breast cancer," Cancer, vol. 116, no. 14, pp. 3348-3356, 2010.

[97] C. B. Harrington, J. A. Hansen, M. Moskowitz, B. L. Todd, and M. Feuerstein, "It's not over when it's over: longterm symptoms in cancer survivors-a systematic review," International Journal of Psychiatry in Medicine, vol. 40, no. 2, pp. 163-181, 2010.

[98] J. Dietrich, M. Monje, J. Wefel, and C. Meyers, "Clinical patterns and biological correlates of cognitive dysfunction associated with cancer therapy," Oncologist, vol. 13, no. 12, pp. 1285-1295, 2008.

[99] M. J. B. Taphoorn and M. Klein, "Cognitive deficits in adult patients with brain tumours," Lancet Neurology, vol. 3, no. 3, pp. 159-168, 2004.

[100] T. N. Byrne, "Cognitive sequelae of brain tumor treatment," Current Opinion in Neurology, vol. 18, no. 6, pp. 662-666, 2005.

[101] M.-E. Brière, J. G. Scott, R. Y. McNall-Knapp, and R. L. Adams, "Cognitive outcome in pediatric brain tumor survivors: delayed attention deficit at long-term follow-up," Pediatric Blood and Cancer, vol. 50, no. 2, pp. 337-340, 2008.

[102] K. Hilverda, I. Bosma, J. J. Heimans et al., "Cognitive functioning in glioblastoma patients during radiotherapy and temozolomide treatment: initial findings," Journal of NeuroOncology, vol. 97, no. 1, pp. 89-94, 2010. 
[103] A. Talacchi, B. Santini, S. Savazzi, and M. Gerosa, "Cognitive effects of tumour and surgical treatment in glioma patients," Journal of Neuro-Oncology, vol. 103, no. 3, pp. 541-549, 2010.

[104] D. D. Correa, "Cognitive functions in brain tumor patients," Hematology/Oncology Clinics of North America, vol. 20, no. 6, pp. 1363-1376, 2006.

[105] J. C. Marsh, B. T. Gielda, A. M. Herskovic, and R. A. Abrams, "Cognitive sparing during the administration of whole brain radiotherapy and prophylactic cranial irradiation: current concepts and approaches," Journal of Oncology, vol. 2010, Article ID 198208, 16 pages, 2010.

[106] M. D. Brandt and A. Storch, "Neurogenesis in the adult brain: from bench to bedside?" Fortschritte der Neurologie Psychiatrie, vol. 76, no. 9, pp. 517-529, 2008.

[107] J. Shen, L. Xie, X. Mao et al., "Neurogenesis after primary intracerebral hemorrhage in adult human brain," Journal of Cerebral Blood Flow and Metabolism, vol. 28, no. 8, pp. 14601468, 2008.

[108] B. Neundörfer, "Does the neurogenesis in the adult brain show the way into the future?" Fortschritte der Neurologie Psychiatrie, vol. 76, no. 9, p. 511, 2008.

[109] J. Liu, K. Solway, R. O. Messing, and F. R. Sharp, "Increased neurogenesis in the dentate gyrus after transient global ischemia in gerbils," Journal of Neuroscience, vol. 18, no. 19, pp. 7768-7778, 1998.

[110] A. Abdipranoto, S. Wu, S. Stayte, and B. Vissel, "The role of neurogenesis in neurodegenerative diseases and its implications for therapeutic development," CNS and Neurological Disorders, vol. 7, no. 2, pp. 187-210, 2008.

[111] V. Chesnokova and R. N. Pechnick, "Antidepressants and Cdk inhibitors: releasing the brake on neurogenesis?" Cell Cycle, vol. 7, no. 15, pp. 2321-2326, 2008.

[112] J. J. Ohab, S. Fleming, A. Blesch, and S. T. Carmichael, "A neurovascular niche for neurogenesis after stroke," Journal of Neuroscience, vol. 26, no. 50, pp. 13007-13016, 2006.

[113] T. D. Palmer, A. R. Willhoite, and F. H. Gage, "Vascular niche for adult hippocampal neurogenesis," Journal of Comparative Neurology, vol. 425, no. 4, pp. 479-494, 2000.

[114] P. S. Eriksson, E. Perfilieva, T. Björk-Eriksson et al., "Neurogenesis in the adult human hippocampus," Nature Medicine, vol. 4, no. 11, pp. 1313-1317, 1998.

[115] N. S. Roy, S. Wang, L. Jiang et al., "In vitro neurogenesis by progenitor cells isolated from the adult human hippocampus," Nature Medicine, vol. 6, no. 3, pp. 271-277, 2000.

[116] F. Doetsch, I. Caille, D. A. Lim, J. M. Garcia-Verdugo, and A. Alvarez-Buylla, "Subventricular zone astrocytes are neural stem cells in the adult mammalian brain," Cell, vol. 97, no. 6, pp. 703-716, 1999.

[117] C. M. Morshead, B. A. Reynolds, C. G. Craig et al., "Neural stem cells in the adult mammalian forebrain: a relatively quiescent subpopulation of subependymal cells," Neuron, vol. 13, no. 5, pp. 1071-1082, 1994.

[118] D.-Z. Liu, B. P. Ander, H. Xu et al., "Blood-brain barrier breakdown and repair by Src after thrombin-induced injury," Annals of Neurology, vol. 67, no. 4, pp. 526-533, 2010.

[119] S. Becker, "A computational principle for hippocampal learning and neurogenesis," Hippocampus, vol. 15, no. 6, pp. 722-738, 2005.

[120] J. B. Aimone, J. Wiles, and F. H. Gage, "Potential role for adult neurogenesis in the encoding of time in new memories," Nature Neuroscience, vol. 9, no. 6, pp. 723-727, 2006.

[121] J. Fallon, S. Reid, R. Kinyamu et al., "In vivo induction of massive proliferation, directed migration, and differentiation of neural cells in the adult mammalian brain," Proceedings of the National Academy of Sciences of the United States of America, vol. 97, no. 26, pp. 14686-14691, 2000.

[122] L. S. Schneider, K. S. Dagerman, J. P. T. Higgins, and R. McShane, "Lack of evidence for the efficacy of memantine in mild Alzheimer disease," Archives of Neurology, vol. 68, no. 8, pp. 991-998, 2011.

[123] M. Suzuki, A. D. Nelson, J. B. Eickstaedt, K. Wallace, L. S. Wright, and C. N. Svendsen, "Glutamate enhances proliferation and neurogenesis in human neural progenitor cell cultures derived from the fetal cortex," European Journal of Neuroscience, vol. 24, no. 3, pp. 645-653, 2006.

[124] X. Zhang, E. D. Yeung, J. Wang et al., "Isoliquiritigenin, a natural anti-oxidant, selectively inhibits the proliferation of prostate cancer cells," Clinical and Experimental Pharmacology and Physiology, vol. 37, no. 8, pp. 841-847, 2010.

[125] K. Abe, "Neuroprotective therapy for ischemic stroke with free radical scavenger and gene-stem cell therapy," Clinical Neurology, vol. 48, no. 11, pp. 896-898, 2008.

[126] C. X. Wang and A. Shuaib, "Neuroprotective effects of free radical scavengers in stroke," Drugs and Aging, vol. 24, no. 7, pp. 537-546, 2007.

[127] K. Eerman and H. Brodaty, "Tocopherol (vitamin E) in Alzheimer's disease and other neurodegenerative disorders," CNS Drugs, vol. 18, no. 12, pp. 807-825, 2004.

[128] J. Viña, A. Lloret, R. Ortí, and D. Alonso, "Molecular bases of the treatment of Alzheimer's disease with antioxidants: prevention of oxidative stress," Molecular Aspects of Medicine, vol. 25, no. 1-2, pp. 117-123, 2004.

[129] K. W. Park and B. K. Jin, "Thrombin-induced oxidative stress contributes to the death of hippocampal neurons: role of neuronal NADPH oxidase," Journal of Neuroscience Research, vol. 86, no. 5, pp. 1053-1063, 2008.

[130] G. Levy, P. Kaufmann, R. Buchsbaum et al., "A two-stage design for a phase II clinical trial of coenzyme Q10 in ALS," Neurology, vol. 66, no. 5, pp. 660-663, 2006.

[131] K. L. Ferrante, J. Shefner, H. Zhang et al., "Tolerance of highdose (3,000 mg/day) coenzyme Q10 in ALS," Neurology, vol. 65, no. 11, pp. 1834-1836, 2005.

[132] H. Yoshino and A. Kimura, "Investigation of the therapeutic effects of edaravone, a free radical scavenger, on amyotrophic lateral sclerosis (Phase II study).," Amyotrophic Lateral Sclerosis, vol. 7, no. 4, pp. 241-245, 2006.

[133] H. Ito, R. Wate, J. Zhang et al., "Treatment with edaravone, initiated at symptom onset, slows motor decline and decreases SOD1 deposition in ALS mice," Experimental Neurology, vol. 213, no. 2, pp. 448-455, 2008.

[134] W. J. Yuan, T. Yasuhara, T. Shingo et al., "Neuroprotective effects of edaravone-administration on 6-OHDA-treated dopaminergic neurons," BMC Neuroscience, vol. 9, article 75, 2008.

[135] M. Tanabe, Y. Nagatani, K. Saitoh, K. Takasu, and H. Ono, "Pharmacological assessments of nitric oxide synthase isoforms and downstream diversity of NO signaling in the maintenance of thermal and mechanical hypersensitivity after peripheral nerve injury in mice," Neuropharmacology, vol. 56, no. 3, pp. 702-708, 2009.

[136] L. Vanella, C. Di Giacomo, R. Acquaviva et al., "The DDAH/ NOS pathway in human prostatic cancer cell lines: antiangiogenic effect of L-NAME," International Journal of Oncology, vol. 39, no. 5, pp. 1303-1310, 2011.

[137] D. Y. Lee, K. W. Park, and B. K. Jin, “Thrombin induces neurodegeneration and microglial activation in the cortex in vivo and in vitro: proteolytic and non-proteolytic actions," 
Biochemical and Biophysical Research Communications, vol. 346, no. 3, pp. 727-738, 2006.

[138] A. L. Sabichi, J. J. Lee, H. B. Grossman et al., "A randomized controlled trial of celecoxib to prevent recurrence of nonmuscle-invasive bladder cancer," Cancer Prevention Research, vol. 4, no. 10, pp. 1580-1589, 2011.

[139] A. Koch, B. Bergman, E. Holmberg et al., "Effect of celecoxib on survival in patients with advanced non-small cell lung cancer: a double blind randomised clinical phase III trial (CYCLUS study) by the Swedish Lung Cancer Study Group," European Journal of Cancer, vol. 47, no. 10, pp. 1546-1555, 2011.

[140] C. Gridelli, C. Gallo, A. Ceribelli et al., "Factorial phase III randomised trial of rofecoxib and prolonged constant infusion of gemcitabine in advanced non-small-cell lung cancer: the GEmcitabine-COxib in NSCLC (GECO) study," Lancet Oncology, vol. 8, no. 6, pp. 500-512, 2007.

[141] J. Kao, E. M. Genden, C.-T. Chen et al., "Phase 1 trial of concurrent erlotinib, celecoxib, and reirradiation for recurrent head and neck cancer," Cancer, vol. 117, no. 14, pp. 31733181, 2011.

[142] A. Lipton, C. Campbell-Baird, L. Witters, H. Harvey, and S. Ali, "Phase II trial of gemcitabine, irinotecan, and celecoxib in patients with advanced pancreatic cancer," Journal of Clinical Gastroenterology, vol. 44, no. 4, pp. 286-288, 2010.

[143] E. S. Antonarakis, E. I. Heath, J. R. Walczak et al., "Phase II, randomized, placebo-controlled trial of neoadjuvant celecoxib in men with clinically localized prostate cancer: evaluation of drug-specific biomarkers," Journal of Clinical Oncology, vol. 27, no. 30, pp. 4986-4993, 2009.

[144] A. Fabi, G. Metro, P. Papaldo et al., "Impact of celecoxib on capecitabine tolerability and activity in pretreated metastatic breast cancer: results of a phase II study with biomarker evaluation," Cancer Chemotherapy and Pharmacology, vol. 62, no. 4, pp. 717-725, 2008.

[145] R. S. Midgley, C. C. McConkey, E. C. Johnstone et al., "Phase III randomized trial assessing rofecoxib in the adjuvant setting of colorectal cancer: final results of the VICTOR trial," Journal of Clinical Oncology, vol. 28, no. 30, pp. 4575-4580, 2010.

[146] M. Youns, T. Efferth, and J. D. Hoheisel, “Transcript profiling identifies novel key players mediating the growth inhibitory effect of NS-398 on human pancreatic cancer cells," European Journal of Pharmacology, vol. 650, no. 1, pp. 170-177, 2011.

[147] A. B. Fernández-Martínez, A. M. Bajo, A. Valdehita et al., "Multifunctional role of VIP in prostate cancer progression in a xenograft model: suppression by curcumin and COX-2 inhibitor NS-398," Peptides, vol. 30, no. 12, pp. 2357-2364, 2009.

[148] L. Zhang, J. Tu, Z.-L. Yu, Y.-D. Wu, C.-M. Xu, and S.T. Zhang, "Effects of the inhibition of cyclooxygenase2 on human esophageal cancer cells: inhibition of cell proliferation and induction of apoptosis," Pathology and Oncology Research, vol. 16, no. 1, pp. 39-45, 2010.

[149] N. Banu, A. Buda, S. Chell et al., "Inhibition of COX-2 with NS-398 decreases colon cancer cell motility through blocking epidermal growth factor receptor transactivation: possibilities for combination therapy," Cell Proliferation, vol. 40, no. 5, pp. 768-779, 2007.

[150] T. D. Warner and J. A. Mitchell, "Cyclooxygenases: new forms, new inhibitors, and lessons from the clinic," FASEB Journal, vol. 18, no. 7, pp. 790-804, 2004.
[151] M. Etminan, S. Gill, and A. Samii, "Effect of non-steroidal anti-inflammatory drugs on risk of Alzheimer's disease: systematic review and meta-analysis of observational studies," British Medical Journal, vol. 327, no. 7407, pp. 128-131, 2003.

[152] J. H. Heo, H. N. Seo, Y. J. Choe et al., "T-type Ca2+ channel blockers suppress the growth of human cancer cells," Bioorganic and Medicinal Chemistry Letters, vol. 18, no. 14, pp. 3899-3901, 2008.

[153] C. L. Franke, R. Palm, M. Dalby et al., "Flunarizine in stroke treatment (FIST): a double-blind, placebo-controlled trial in Scandinavia and the Netherlands," Acta Neurologica Scandinavica, vol. 93, no. 1, pp. 56-60, 1996.

[154] W. G. North, G. Gao, V. A. Memoli, R. H. Pang, and L. Lynch, "Breast cancer expresses functional NMDA receptors," Breast Cancer Research and Treatment, vol. 122, no. 2, pp. 307-314, 2010.

[155] H. Yang, M. Chopp, F. Jiang, X. Zhang, and T. Schallert, "Interruption of functional recovery by the NMDA glutamate antagonist MK801 after compression of the sensorimotor cortex: implications for treatment of tumors or other mass-related brain injuries," Experimental Neurology, vol. 200, no. 1, pp. 262-266, 2006.

[156] J. Andrews, "Amyotrophic lateral sclerosis: clinical management and research update," Current Neurology and Neuroscience Reports, vol. 9, no. 1, pp. 59-68, 2009.

[157] T. K. McIntosh, D. H. Smith, M. Voddi, B. R. Perri, and J.-M. Stutzmann, "Riluzole, a novel neuroprotective agent, attenuates both neurologic motor and cognitive dysfunction following experimental brain injury in the rat," Journal of Neurotrauma, vol. 13, no. 12, pp. 767-780, 1996.

[158] L. Belayev, O. F. Alonso, Y. Liu et al., "Talampanel, a novel noncompetitive AMPA antagonist, is neuroprotective after traumatic brain injury in rats," Journal of Neurotrauma, vol. 18, no. 10, pp. 1031-1038, 2001.

[159] P. H. Kitzman, "Effectiveness of riluzole in suppressing spasticity in the spinal cord injured rat," Neuroscience Letters, vol. 455, no. 2, pp. 150-153, 2009.

[160] T. D. Ardizzone, A. Lu, K. R. Wagner, Y. Tang, R. Ran, and F. R. Sharp, "Glutamate receptor blockade attenuates glucose hypermetabolism in perihematomal brain after experimental intracerebral hemorrhage in rat," Stroke, vol. 35, no. 11, pp. 2587-2591, 2004.

[161] P. Meden, K. Overgaard, T. Sereghy, and G. Boysen, "Enhancing the efficacy of thrombolysis by AMPA receptor blockade with NBQX in a rat embolic stroke model," Journal of the Neurological Sciences, vol. 119, no. 2, pp. 209-216, 1993.

[162] K. Watanabe, T. Kanno, T. Oshima, H. Miwa, C. Tashiro, and T. Nishizaki, "The NMDA receptor NR2A subunit regulates proliferation of MKN45 human gastric cancer cells," Biochemical and Biophysical Research Communications, vol. 367, no. 2, pp. 487-490, 2008.

[163] W. Danysz and C. G. Parsons, "The NMDA receptor antagonist memantine as a symptomatological and neuroprotective treatment for Alzheimer's disease: preclinical evidence," International Journal of Geriatric Psychiatry, vol. 18, no. 1, pp. S23-S32, 2003.

[164] J. L. Molinuevo, A. Lladó, and L. Rami, "Memantine: targeting glutamate excitotoxicity in Alzheimer's disease and other dementias," American Journal of Alzheimer's Disease and other Dementias, vol. 20, no. 2, pp. 77-85, 2005.

[165] D. M. Robinson and G. M. Keating, "Memantine: a review of its use in Alzheimer's disease," Drugs, vol. 66, no. 11, pp. 1515-1534, 2006. 
[166] A. Iraqi and T. L. Hughes, "Nightmares and memantine: a case report and review of literature," Journal of the American Medical Directors Association, vol. 10, no. 1, pp. 77-78, 2009.

[167] K. Zdanys and R. R. Tampi, "A systematic review of offlabel uses of memantine for psychiatric disorders," Progress in Neuro-Psychopharmacology and Biological Psychiatry, vol. 32, no. 6, pp. 1362-1374, 2008.

[168] V. L. Raghavendra Rao, A. Dogan, K. G. Todd, K. K. Bowen, and R. J. Dempsey, "Neuroprotection by memantine, a noncompetitive NMDA receptor antagonist after traumatic brain injury in rats," Brain Research, vol. 911, no. 1, pp. 96-100, 2001.

[169] S.-T. Lee, K. Chu, K.-H. Jung et al., "Memantine reduces hematoma expansion in experimental intracerebral hemorrhage, resulting in functional improvement," Journal of Cerebral Blood Flow and Metabolism, vol. 26, no. 4, pp. 536$544,2006$.

[170] C. S. Babu and M. Ramanathan, "Pre-ischemic treatment with memantine reversed the neurochemical and behavioural parameters but not energy metabolites in middle cerebral artery occluded rats," Pharmacology Biochemistry and Behavior, vol. 92, no. 3, pp. 424-432, 2009.

[171] L. Yu, H. G. Garg, B. Li, R. J. Linhardt, and C. A. Hales, "Antitumor effect of butanoylated heparin with low anticoagulant activity on lung cancer growth in mice and rats," Current Cancer Drug Targets, vol. 10, no. 2, pp. 229241, 2010.

[172] R. Mikulík, M. Dufek, D. Goldemund, and M. Reif, "A pilot study on systemic thrombolysis followed by low molecular weight heparin in ischemic stroke," European Journal of Neurology, vol. 13, no. 10, pp. 1106-1111, 2006.

[173] Z. Sun, Z. Zhao, S. Zhao et al., "Recombinant hirudin treatment modulates aquaporin-4 and aquaporin- 9 expression after intracerebral hemorrhage in vivo," Molecular Biology Reports, vol. 36, no. 5, pp. 1119-1127, 2009.

[174] M. Xue, M. D. Hollenberg, and V. W. Yong, "Combination of thrombin and matrix metalloproteinase-9 exacerbates neurotoxicity in cell culture and intracerebral hemorrhage in mice," Journal of Neuroscience, vol. 26, no. 40, pp. 1028110291, 2006.

[175] T. Goerge, A. Barg, E. M. Schnaeker et al., "Tumor-derived matrix metalloproteinase- 1 targets endothelial proteinaseactivated receptor 1 promoting endothelial cell activation," Cancer Research, vol. 66, no. 15, pp. 7766-7774, 2006.

[176] C. E. Junge, T. Sugawara, G. Mannaioni et al., "The contribution of protease-activated receptor 1 to neuronal damage caused by transient focal cerebral ischemia," Proceedings of the National Academy of Sciences of the United States of America, vol. 100, no. 22, pp. 13019-13024, 2003.

[177] C. E. Hamill, W. M. Caudle, J. R. Richardson et al., "Exacerbation of dopaminergic terminal damage in a mouse model of Parkinson's disease by the G-protein-coupled receptor protease-activated receptor 1," Molecular Pharmacology, vol. 72, no. 3, pp. 653-664, 2007.

[178] M. T. Acosta, P. G. Kardel, K. S. Walsh, K. N. Rosenbaum, G. A. Gioia, and R. J. Packer, "Lovastatin as treatment for neurocognitive deficits in neurofibromatosis type 1: phase I study," Pediatric Neurology, vol. 45, no. 4, pp. 241-245, 2011.

[179] J. J. Knox, L. L. Siu, E. Chen et al., "A Phase I trial of prolonged administration of lovastatin in patients with recurrent or metastatic squamous cell carcinoma of the head and neck or of the cervix," European Journal of Cancer, vol. 41, no. 4, pp. 523-530, 2005.
[180] B. Barkan, S. Starinsky, E. Friedman, R. Stein, and Y. Kloog, "The Ras inhibitor farnesylthiosalicylic acid as a potential therapy for neurofibromatosis type 1," Clinical Cancer Research, vol. 12, no. 18, pp. 5533-5542, 2006.

[181] L. Björkhem-Bergman, J. Acimovic, U. B. Torndal, P. Parini, and L. C. Eriksson, "Lovastatin prevents carcinogenesis in a rat model for liver cancer. Effects of ubiquinone supplementation," Anticancer Research, vol. 30, no. 4, pp. 1105-1112, 2010.

[182] A. Martirosyan, J. W. Clendening, C. A. Goard, and L. Z. Penn, "Lovastatin induces apoptosis of ovarian cancer cells and synergizes with doxorubicin: potential therapeutic relevance," BMC Cancer, vol. 10, article 103, 2010.

[183] J. Klawitter, T. Shokati, V. Moll, U. Christians, and J. Klawitter, "Effects of lovastatin on breast cancer cells: a proteo-metabonomic study," Breast Cancer Research, vol. 12, no. 2, article R16, 2010.

[184] J. Lee, I. Lee, C. Park, and W. K. Kang, "Lovastatin-induced RhoA modulation and its effect on senescence in prostate cancer cells," Biochemical and Biophysical Research Communications, vol. 339, no. 3, pp. 748-754, 2006.

[185] I. H. Park, J. Y. Kim, J. I. Jung, and J. Y. Han, "Lovastatin overcomes gefitinib resistance in human non-small cell lung cancer cells with K-Ras mutations," Investigational New Drugs, vol. 28, no. 6, pp. 791-799, 2010.

[186] M. S. V. Elkind, R. L. Sacco, R. B. Macarthur et al., "The Neuroprotection with Statin Therapy for Acute Recovery Trial (NeuSTART): an adaptive design phase I dose-escalation study of high-dose lovastatin in acute ischemic stroke," International Journal of Stroke, vol. 3, no. 3, pp. 210-218, 2008.

[187] M. S. V. Elkind, R. L. Sacco, R. B. MacArthur et al., "Highdose lovastatin for acute ischemic stroke: results of the phase I dose escalation Neuroprotection with Statin Therapy for Acute Recovery Trial (NeuSTART)," Cerebrovascular Diseases, vol. 28, no. 3, pp. 266-275, 2009.

[188] I. V. Smirnova, B. A. Citron, P. M. Arnold, and B. W. Festoff, "Neuroprotective signal transduction in model motor neurons exposed to thrombin: G-protein modulation effects on neurite outgrowth, Ca2+ mobilization, and apoptosis," Journal of Neurobiology, vol. 48, no. 2, pp. 87-100, 2001.

[189] D. D. Cunningham, "Thrombin induces apoptosis in cultured neurons and astrocytes via a pathway requiring tyrosine kinase and RhoA activities," Journal of Neuroscience, vol. 17, no. 14, pp. 5316-5326, 1997.

[190] C. I. Herold, V. Chadaram, B. L. Peterson et al., "Phase II trial of dasatinib in patients with metastatic breast cancer using real-time pharmacodynamic tissue biomarkers of Src inhibition to escalate dosing," Clinical Cancer Research, vol. 17, no. 18, pp. 6061-6070, 2011.

[191] A. Gucalp, J. A. Sparano, J. Caravelli et al., "Phase II trial of saracatinib (AZD0530), an oral SRC-inhibitor for the treatment of patients with hormone receptor-negative metastatic breast cancer," Clinical Breast Cancer, vol. 11, no. 5, pp. 306-311, 2011.

[192] M. Anbalagan, L. Carrier, S. Glodowski, D. Hangauer, B. Shan, and B. G. Rowan, "KX-01, a novel Src kinase inhibitor directed toward the peptide substrate site, synergizes with tamoxifen in estrogen receptor alpha positive breast cancer," Breast Cancer Research and Treatment. In press.

[193] B. Pohorelic, R. Singh, S. Parkin et al., "Role of Src in breast cancer cell migration and invasion in a breast cell/bonederived cell microenvironment," Breast Cancer Research and Treatment. In press. 
[194] P. Ceppi, I. Rapa, M. Lo Iacono et al., "Expression and pharmacological inhibition of thymidylate synthase and Src kinase in nonsmall cell lung cancer," International Journal of Cancer. In press.

[195] G. W. Krystal, C. S. DeBerry, D. Linnekin, and J. Litz, "Lck associates with and is activated by kit in a small cell lung cancer cell line: inhibition of SCF-mediated growth by the Src family kinase inhibitor PP1," Cancer Research, vol. 58, no. 20, pp. 4660-4666, 1998.

[196] L. Kong, Z. Deng, H. Shen, and Y. Zhang, "Src family kinase inhibitor PP2 efficiently inhibits cervical cancer cell proliferation through down-regulating phospho-Src-Y416 and phospho-EGFR-Y1173," Molecular and Cellular Biochemistry, vol. 348, no. 1-2, pp. 11-19, 2011.

[197] E. Fujimoto, H. Sato, Y. Nagashima et al., "A Src family inhibitor (PP1) potentiates tumor-suppressive effect of connexin 32 gene in renal cancer cells," Life Sciences, vol. 76, no. 23, pp. 2711-2720, 2005.

[198] L. Li, C. H. Ren, S. A. Tahir, C. Ren, and T. C. Thompson, "Caveolin-1 maintains activated Akt in prostate cancer cells through scaffolding domain binding site interactions with and inhibition of serine/threonine protein phosphatases PP1 and PP2A," Molecular and Cellular Biology, vol. 23, no. 24, pp. 9389-9404, 2003.

[199] T. D. Ardizzone, X. Zhan, B. P. Ander, and F. R. Sharp, "Src kinase inhibition improves acute outcomes after experimental intracerebral hemorrhage," Stroke, vol. 38, no. 5, pp. 16211625, 2007.

[200] I. A. Siddiqui, M. Asim, B. B. Hafeez, V. M. Adhami, R. S. Tarapore, and H. Mukhtar, "Green tea polyphenol EGCG blunts androgen receptor function in prostate cancer," FASEB Journal, vol. 25, no. 4, pp. 1198-1207, 2011.

[201] T. Sen, A. Dutta, and A. Chatterjee, "Epigallocatechin-3gallate (EGCG) downregulates gelatinase-B (MMP-9) by involvement of FAK/ERK/NF $\kappa$ B and AP-1 in the human breast cancer cell line MDA-MB-231," Anti-Cancer Drugs, vol. 21, no. 6, pp. 632-644, 2010.

[202] S. A. Milligan, P. Burke, D. T. Coleman et al., "The green tea polyphenol EGCG potentiates the antiproliferative activity of c-Met and epidermal growth factor receptor inhibitors in non-small cell lung cancer cells," Clinical Cancer Research, vol. 15, no. 15, pp. 4885-4894, 2009.

[203] S. Shankar, S. Ganapathy, S. R. Hingorani, and R. K. Srivastava, "EGCG inhibits growth, invasion, angiogenesis and metastasis of pancreatic cancer," Frontiers in Bioscience, vol. 13, no. 2, pp. 440-452, 2008.

[204] S. Faderl, A. Ferrajoli, D. Harris, Q. Van, W. Priebe, and Z. Estrov, "WP-1034, a novel JAK-STAT inhibitor, with proapoptotic and antileukemic activity in acute myeloid leukemia (AML)," Anticancer Research, vol. 25, no. 3 B, pp. 1841-1850, 2005.

[205] A. Shakoori, W. Mai, K. Miyashita et al., "Inhibition of GSK$3 \beta$ activity attenuates proliferation of human colon cancer cells in rodents," Cancer Science, vol. 98, no. 9, pp. 1388-1393, 2007.

[206] J. G. Pizarro, J. Folch, J. L. Esparza, J. Jordan, M. Pallàs, and A. Camins, "A molecular study of pathways involved in the inhibition of cell proliferation in neuroblastoma B65 cells by the GSK-3 inhibitors lithium and SB-415286," Journal of Cellular and Molecular Medicine, vol. 13, no. 9 B, pp. 39063917, 2009.

[207] M. Pallàs and A. Camins, "Molecular and biochemical features in Alzheimer's disease," Current Pharmaceutical Design, vol. 12, no. 33, pp. 4389-4408, 2006.
[208] R. V. Bhat, S. L. Budd Haeberlein, and J. Avila, "Glycogen synthase kinase 3: a drug target for CNS therapies," Journal of Neurochemistry, vol. 89, no. 6, pp. 1313-1317, 2004.

[209] D. A. E. Cross, A. A. Culbert, K. A. Chalmers, L. Facci, S. D. Skaper, and A. D. Reith, "Selective small-molecule inhibitors of glycogen synthase kinase-3 activity protect primary neurones from death," Journal of Neurochemistry, vol. 77, no. 1, pp. 94-102, 2001.

[210] R. S. Jope and G. V. W. Johnson, "The glamour and gloom of glycogen synthase kinase-3," Trends in Biochemical Sciences, vol. 29, no. 2, pp. 95-102, 2004.

[211] N. Dunn, C. Holmes, and M. Mullee, "Does lithium therapy protect against the onset of dementia?" Alzheimer Disease and Associated Disorders, vol. 19, no. 1, pp. 20-22, 2005.

[212] Y. Su, J. Ryder, B. Li et al., "Lithium, a common drug for bipolar disorder treatment, regulates amyloid- $\beta$ precursor protein processing," Biochemistry, vol. 43, no. 22, pp. 68996908, 2004

[213] E. S. Chung, E. Bok, S. Sohn, Y. D. Lee, H. H. Baik, and B. K. Jin, "GT1b-induced neurotoxicity is mediated by the Akt/GSK-3/tau signaling pathway but not caspase-3 in mesencephalic dopaminergic neurons," BMC Neuroscience, vol. 11, article 74, 2010.

[214] H. Jiang, W. Guo, X. Liang, and Y. Rao, "Both the establishment and the maintenance of neuronal polarity require active mechanisms: critical roles of GSK-3 $\beta$ and its upstream regulators," Cell, vol. 120, no. 1, pp. 123-135, 2005.

[215] F. Fornai, P. Longone, L. Cafaro et al., "Lithium delays progression of amyotrophic lateral sclerosis," Proceedings of the National Academy of Sciences of the United States of America, vol. 105, no. 6, pp. 2052-2057, 2008.

[216] E. Leung, J. E. Kim, G. W. Rewcastle, G. J. Finlay, and B. C. Baguley, "Comparison of the effects of the PI3K/mTOR inhibitors NVP-BEZ235 and GSK2126458 on tamoxifenresistant breast cancer cells," Cancer Biology and Therapy, vol. 11, no. 11, pp. 938-946, 2011.

[217] L. Zhao, B. Teter, T. Morihara et al., "Insulin-degrading enzyme as a downstream target of insulin receptor signaling cascade: implications for Alzheimer's disease intervention," Journal of Neuroscience, vol. 24, no. 49, pp. 11120-11126, 2004.

[218] S.-N. Kim, S.-T. Kim, A.-R. Doo et al., "Phosphatidylinositol 3-kinase/Akt signaling pathway mediates acupunctureinduced dopaminergic neuron protection and motor function improvement in a mouse model of parkinson's disease," International Journal of Neuroscience, vol. 121, no. 10, pp. 562-569, 2011.

[219] L. Van Ummersen, K. Binger, J. Volkman et al., "A phase I trial of perifosine (NSC 639966) on a loading dose/maintenance dose schedule in patients with advanced cancer," Clinical Cancer Research, vol. 10, no. 22, pp. 7450-7456, 2004.

[220] S. K. Pal, K. Reckamp, H. Yu, and R. A. Figlin, "Akt inhibitors in clinical development for the treatment of cancer," Expert Opinion on Investigational Drugs, vol. 19, no. 11, pp. 13551366, 2010.

[221] “(1995-2011) FDA Approved Drugs for Oncology,” http:// www.centerwatch.com/drug-information/fda-approvals/ drug-areas.aspx?AreaID=12.

[222] K. Behbakht, M. W. Sill, K. M. Darcy et al., "Phase II trial of the mTOR inhibitor, temsirolimus and evaluation of circulating tumor cells and tumor biomarkers in persistent and recurrent epithelial ovarian and primary peritoneal malignancies. A Gynecologic Oncology Group study," Gynecologic Oncology, vol. 123, no. 1, pp. 19-26, 2011. 
[223] A. M. Oza, L. Elit, M.-S. Tsao et al., "Phase II study of temsirolimus in women with recurrent or metastatic endometrial cancer: a trial of the NCIC Clinical Trials Group," Journal of Clinical Oncology, vol. 29, no. 24, pp. 3278-3285, 2011.

[224] S. Chan, M. E. Scheulen, S. Johnston et al., "Phase II study of temsirolimus (CCI-779), a novel inhibitor of mTOR, in heavily pretreated patients with locally advanced or metastatic breast cancer," Journal of Clinical Oncology, vol. 23, no. 23, pp. 5314-5322, 2005.

[225] E. Galanis, J. C. Buckner, M. J. Maurer et al., "Phase II trial of temsirolimus (CCI-779) in recurrent glioblastoma multiforme: a north central cancer treatment group study," Journal of Clinical Oncology, vol. 23, no. 23, pp. 5294-5304, 2005.

[226] I. Duran, J. Kortmansky, D. Singh et al., "A phase II clinical and pharmacodynamic study of temsirolimus in advanced neuroendocrine carcinomas," British Journal of Cancer, vol. 95, no. 9, pp. 1148-1154, 2006.

[227] K. J. Pandya, S. Dahlberg, M. Hidalgo et al., "A randomized, phase II trial of two dose levels of temsirolimus (CCI-779) in patients with extensive-stage small-cell lung cancer who have responding or stable disease after induction chemotherapy: a trial of the Eastern Cooperative Oncology Group (E1500)," Journal of Thoracic Oncology, vol. 2, no. 11, pp. 1036-1041, 2007.

[228] H. Gerullis, T. H. Ecke, B. Janusch et al., "Long-term response in advanced bladder cancer involving the use of temsirolimus and vinflunine after platin resistance," Anti-Cancer Drugs, vol. 22, no. 9, pp. 940-943, 2011.

[229] D. Zardavas, A. Meisel, P. Samaras et al., "Temsirolimus is highly effective as third-line treatment in chromophobe renal cell cancer," Case Reports in Oncology, vol. 4, no. 1, pp. 16-18, 2011.

[230] G. Hudes, M. Carducci, P. Tomczak et al., "Temsirolimus, interferon alfa, or both for advanced renal-cell carcinoma," New England Journal of Medicine, vol. 356, no. 22, pp. 22712281, 2007.

[231] P. Spilman, N. Podlutskaya, M. J. Hart et al., "Inhibition of mTOR by rapamycin abolishes cognitive deficits and reduces amyloid- $\beta$ levels in a mouse model of alzheimer's disease," PLoS ONE, vol. 5, no. 4, article e9979, 2010.

[232] C. Malagelada, Z. H. Jin, V. Jackson-Lewis, S. Przedborski, and L. A. Greene, "Rapamycin protects against neuron death in in vitro and in vivo models of Parkinson's disease," Journal of Neuroscience, vol. 30, no. 3, pp. 1166-1175, 2010.

[233] S. Chen, C. M. Atkins, C. L. Liu, O. F. Alonso, W. D. Dietrich, and B. R. Hu, "Alterations in mammalian target of rapamycin signaling pathways after traumatic brain injury," Journal of Cerebral Blood Flow and Metabolism, vol. 27, no. 5, pp. 939949, 2007.

[234] J. Park, J. Zhang, J. Qiu et al., "Combination therapy targeting Akt and mammalian target of rapamycin improves functional outcome after controlled cortical impact in mice," Journal of Cerebral Blood Flow and Metabolism. In press.

[235] S. Codeluppi, C. I. Svensson, M. P. Hefferan et al., "The RhebmTOR pathway is upregulated in reactive astrocytes of the injured spinal cord," Journal of Neuroscience, vol. 29, no. 4, pp. 1093-1104, 2009.

[236] A. Sekiguchi, H. Kanno, H. Ozawa, S. Yamaya, and E. Itoi, "Rapamycin Promotes Autophagy and Reduces Neural Tissue Damage and Locomotor Impairment after Spinal Cord Injury in Mice," Journal of Neurotrauma. In press.

[237] A. Chauhan, U. Sharma, N. R. Jagannathan, K. H. Reeta, and Y. K. Gupta, "Rapamycin protects against middle cerebral artery occlusion induced focal cerebral ischemia in rats," Behavioural Brain Research, vol. 225, no. 2, pp. 603-609, 2011.

[238] A. Jimeno, G. Hallur, A. Chan et al., "Development of two novel benzoylphenylurea sulfur analogues and evidence that the microtubule-associated protein tau is predictive of their activity in pancreatic cancer," Molecular Cancer Therapeutics, vol. 6, no. 5, pp. 1509-1516, 2007.

[239] TauRx-Therapeutics-Ltd, "TRx0014 in Patients With Mild or Moderate Alzheimer's Disease. ClinicalTrials.gov Identifier: NCT00515333," 2007, http://clinicaltrials.gov/ct2/ show $/$ NCT00515333?spons $=\% 22 \mathrm{TauRx}+$ Therapeutics+ Ltd\%22\&spons_ex=Y\&rank=1.

[240] M. Williams, "Progress in Alzheimer's disease drug discovery: an update," Current Opinion in Investigational Drugs, vol. 10, no. 1, pp. 23-34, 2009.

[241] S. Zelivianski, M. Spellman, M. Kellerman et al., "ERK inhibitor PD98059 enhances docetaxel-induced apoptosis of androgen-independent human prostate cancer cells," International Journal of Cancer, vol. 107, no. 3, pp. 478-485, 2003.

[242] H. H. Yong, J. M. Hwa, B. R. You et al., "The MEK inhibitor PD98059 attenuates growth inhibition and death in gallic acid-treated Calu-6 lung cancer cells by preventing glutathione depletion," Molecular Medicine Reports, vol. 3, no. 3, pp. 519-524, 2010.

[243] S. J. Lim, Y. J. Lee, and E. Lee, "p38MAPK inhibitor SB203580 sensitizes human SNU-C4 colon cancer cells to exisulindinduced apoptosis," Oncology Reports, vol. 16, no. 5, pp. 1131-1135, 2006.

[244] S. Karunakaran, U. Saeed, M. Mishra et al., "Selective activation of p38 mitogen-activated protein kinase in dopaminergic neurons of substantia nigra leads to nuclear translocation of p53 in 1-methyl-4-phenyl-1,2,3,6-tetrahydropyridinetreated mice," Journal of Neuroscience, vol. 28, no. 47, pp. 12500-12509, 2008.

[245] F. C. Barone, E. A. Irving, A. M. Ray et al., "Inhibition of p38 mitogen-activated protein kinase provides neuroprotection in cerebral focal ischemia," Medicinal Research Reviews, vol. 21, no. 2, pp. 129-145, 2001.

[246] S. Martial, J.-L. Giorgelli, A. Renaudo, B. Derijard, and O. Soriani, "SP600125 inhibits Kv channels through a JNK-independent pathway in cancer cells," Biochemical and Biophysical Research Communications, vol. 366, no. 4, pp. 944-950, 2008.

[247] J.-H. Kim, T. H. Kim, H. S. Kang, J. Ro, H. S. Kim, and S. Yoon, "SP600125, an inhibitor of Jnk pathway, reduces viability of relatively resistant cancer cells to doxorubicin," Biochemical and Biophysical Research Communications, vol. 387, no. 3, pp. 450-455, 2009.

[248] L. H. Wang, C. G. Besirli, and E. M. Johnson Jr., "Mixedlineage kinases: a target for the prevention of neurodegeneration," Annual Review of Pharmacology and Toxicology, vol. 44, pp. 451-474, 2004.

[249] J. Leszek, A. D. Inglot, M. Janusz et al., "Colostrinin prolinerich polypeptide complex from ovine colostrum-a longterm study of its efficacy in Alzheimer's disease," Medical Science Monitor, vol. 8, no. 10, pp. PI93-PI96, 2002.

[250] C. Y. Kuan and R. E. Burke, "Targeting the JNK signaling pathway for stroke and parkinson's diseases therapy," Current Drug Targets, vol. 4, no. 1, pp. 63-67, 2005. 

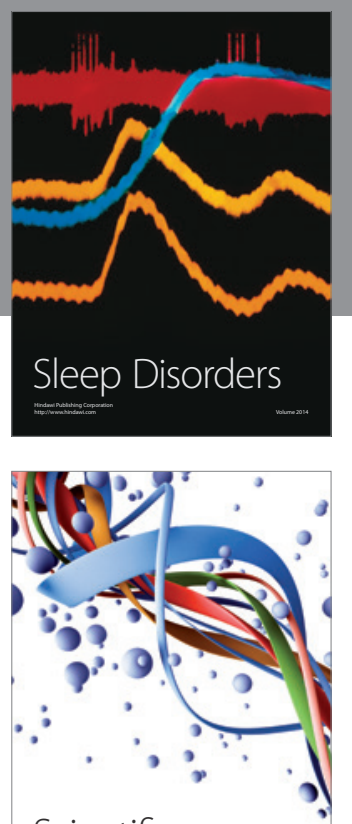

Scientifica
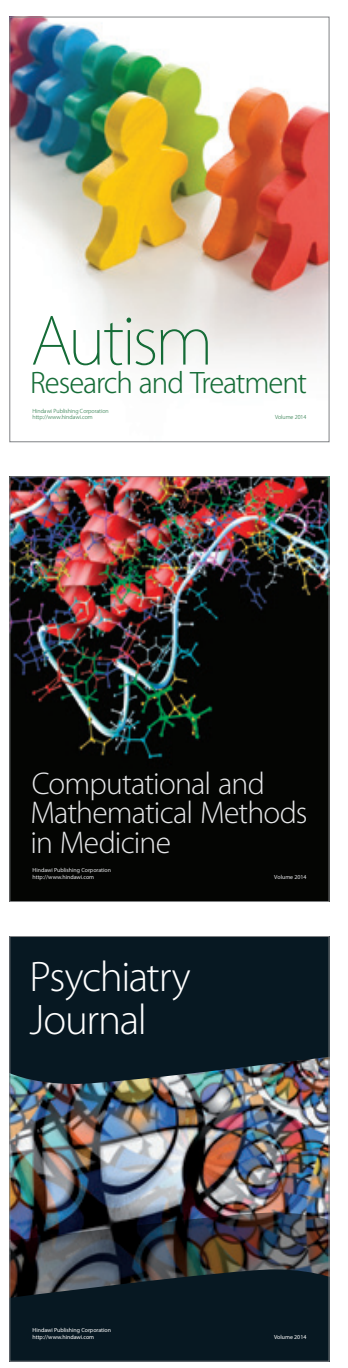
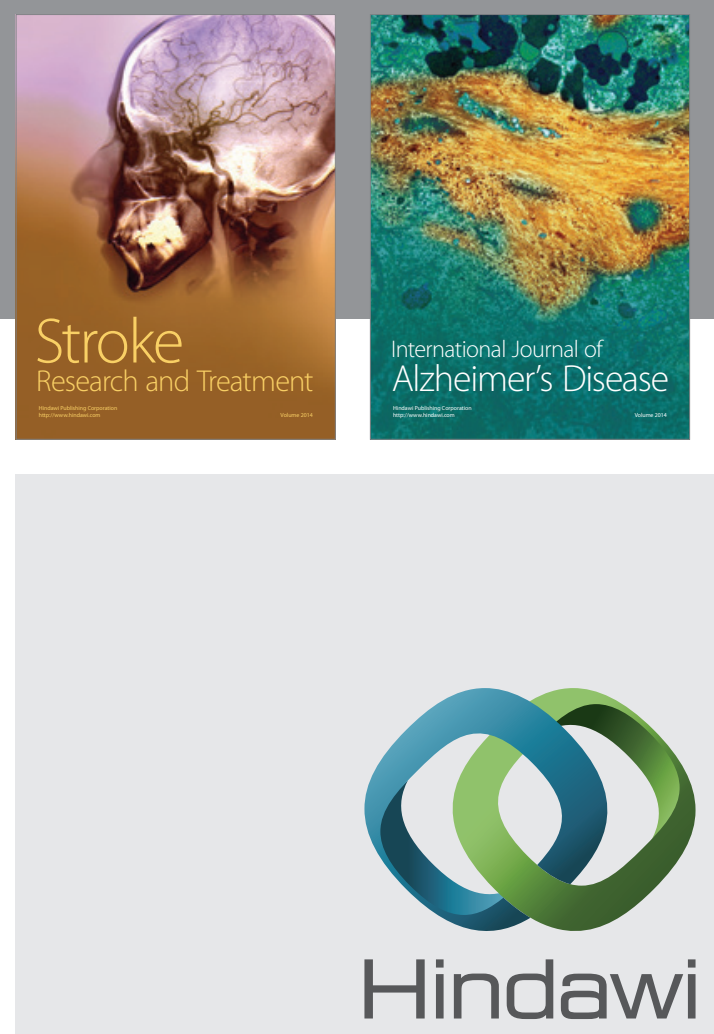

Submit your manuscripts at

http://www.hindawi.com
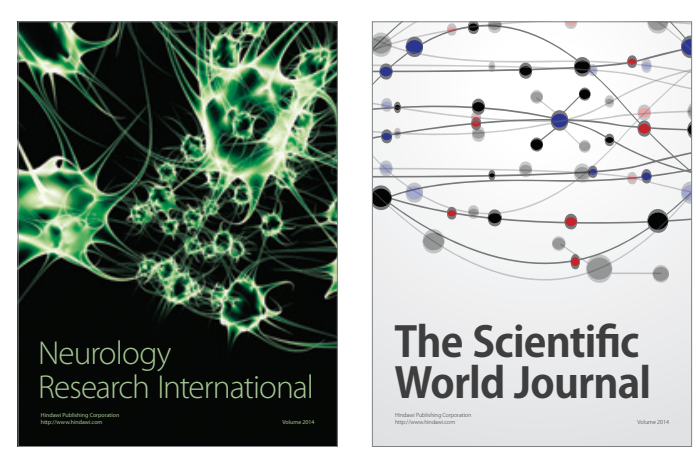

The Scientific World Journal

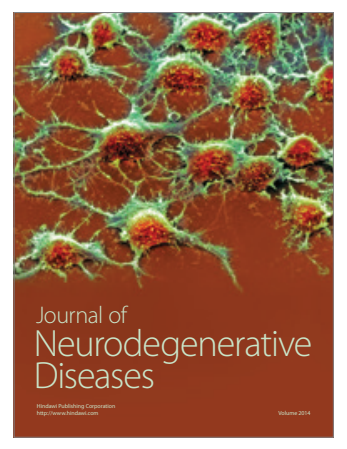

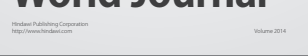

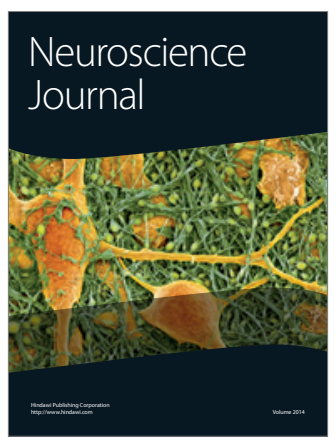

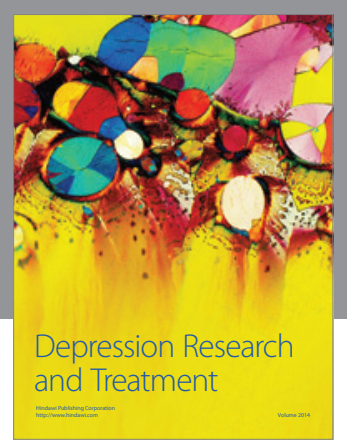
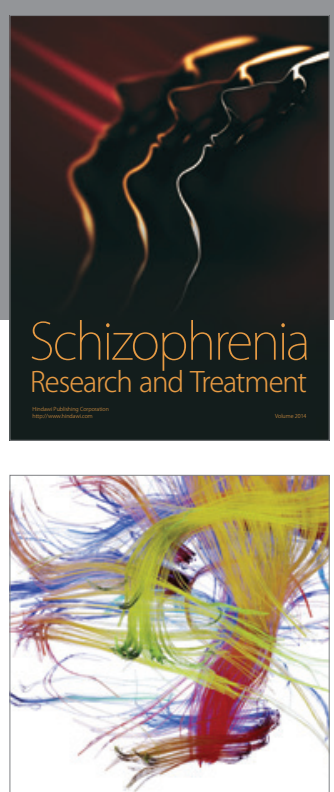

Brain Science

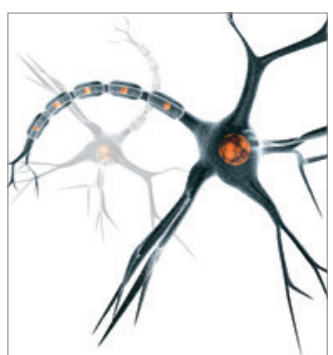

Neural Plasticity
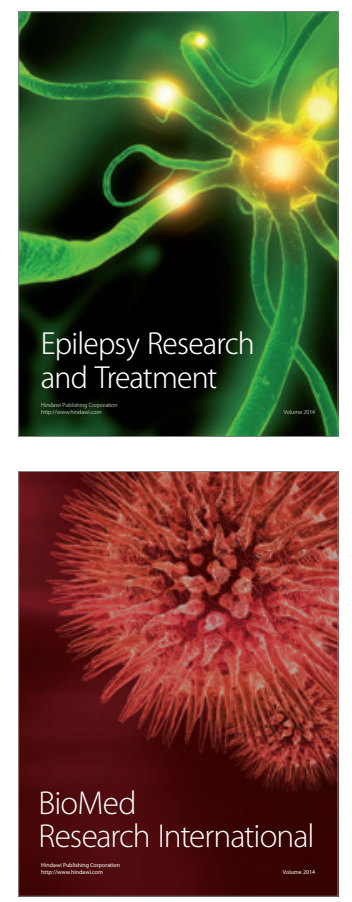

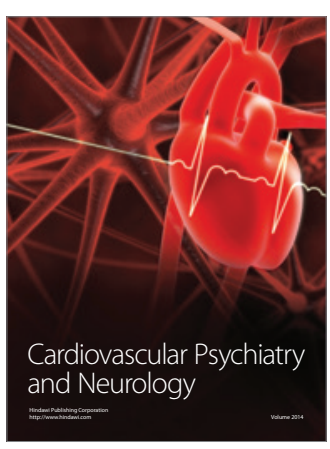

Parkinson's

Disease
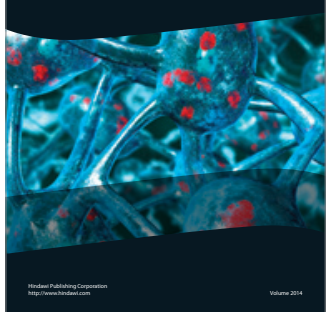